\title{
Entrepreneurs' human capital and growth aspirations: the moderating role of regional entrepreneurial culture
}

\section{Introduction}

The aspiration of entrepreneurs to grow reflects their respective individual beliefs about the potential of their ventures (Levie and Autio 2013). As such, evidence shows a wide variation in entrepreneurial growth aspirations (Gilbert et al. 2006; Wright and Stigliani 2013), which is reflected in differences in subsequent real firm growth (Baum et al. 2001; Davidsson et al. 2006; Wiklund and Shepherd 2003). Further, the rate of entrepreneurs who aspire to extensively grow their firms has been found to contribute more strongly to economic growth than the entrepreneurship rate in general (Hermans et al. 2015).

These findings explain the increasing interest in how entrepreneurs developed their beliefs about firm growth (Autio and Acs 2010; Autio et al. 2013; Estrin et al. 2013; Giotopoulos et al. 2016; Puente et al. 2016). Yet, more study is required to understand how both individual characteristics and external conditions affect their growth aspirations. This paper contributes to our knowledge about the formation of entrepreneurial growth aspirations by focusing on two under-research but important issues: (1) the direct effects of general and human capital on such aspirations, and (2) the moderating role of regional entrepreneurial culture on the link between human capital attributes and aspirations.

In this respect, prior research has shown that human capital is important for all entrepreneurs in the formation of their growth aspirations (Autio and Acs, 2010). However, these authors focused solely on general human capital, namely formal education, leaving unstudied the influence of a major source of specific human capital: prior entrepreneurial experience (Estrin et al. 2016; Wiklund and Shepherd 2003). The first novelty of our study is that we argue that, opposite to the case of entrepreneurs with higher educational attainment, 
experienced entrepreneurs will have lower aspirations. This is because they have not only lower opportunity costs than highly educated individuals but also because they have a specific knowledge base which allows them to be more realistic in the assessment of the prospects of the new venture (Westhead et al. 2009; Wright and Stigliani 2013).

Secondly, we argue that the impact of general and specific human capital on aspirations will depend on aspects of the regional institutional context. We focus on the potential moderating role of the regional entrepreneurial culture (Beugelsdijk 2007; Freytag and Thurik 2007; Foreman-Peck and Zhou 2013). In particular, we concentrate on two core elements of this culture: the legitimacy or social acceptance of entrepreneurship (Kibler et al. 2014) and the availability of social capital in the form of trust-based networks that include regional role models (Westlund et al. 2014). We posit that the existence of a supportive entrepreneurial culture in the region, indicated by higher levels of social acceptance of entrepreneurship and accessible role models, will positively moderate the effect of human capital on growth aspirations. This is novel in the regional entrepreneurship literature, since only Kibler et al. (2014) have previously investigated the moderating influence of regional entrepreneurial culture but they studied its role in shaping entrepreneurial intentions and behavior.

We test our hypotheses on a large cross-regional data set that combines individual-level information obtained from the Global Entrepreneurship Monitor (GEM) project in Spain with province-level information gathered from the Spanish Statistics Institute, EUROSTAT and the GEM project during the time period 2008-2014. Our hypotheses are tested by way of a multilevel analysis, as in our research context individuals (early-stage entrepreneurs) are nested within geographical areas (provinces).

This research makes several contributions to the literature. First, it broadens our understanding of the role of human capital in explaining entrepreneurial growth aspirations. 
As such, it shows that not all forms of human capital have the same effect on such aspirations. Specifically, general human capital (i.e. educational attainment) has a positive effect on aspirations because both their assessments of the growth potential of their ventures and the opportunity cost of occupational choice increase with the level of education (Autio and Acs 2010); whereas specific human capital (i.e. prior entrepreneurial experience) has a negative impact as experienced entrepreneurs will tend to be more realistic in their predictions. Second, our research offers a more contextualized understanding of the impact of human capital investments on growth aspirations, advancing that their effects on growth aspirations are influenced by the regional cultural context in which the individual is located. More precisely, we show that a regional supportive entrepreneurial culture positively moderates the impact of specific human capital on growth aspirations, whereas the growth aspirations of more educated individuals are only affected by the presence of role models. This stresses the relevance of the close cultural context (i.e. region) to determine aspirations, and completes previous research (Autio et al. 2013) that has established the importance of national level cultural values. Finally, the study combines measures from two different levels of analysis, namely, individual and regional levels, responding to calls for greater consideration of context and multilevel studies in ambitious entrepreneurship (Hermans et al. 2015).

The rest of the paper is organized as follows. We start by developing and justifying four testable hypotheses; next we describe the data as well as our variables and methods used. After presenting the results of our empirical analysis, we conclude by discussing the implications of this research. 


\section{Theory and hypotheses}

\subsection{Human capital and growth aspirations}

Becker (1964) developed a theory of investments in human capital based on previous views about human capital (Mincer 1958; Schultz 1961) and the evidence that highly educated individuals tend to earn more than others. According to this theory, individuals can purposely invest in their human capital and acquire knowledge and experience (Marvel 2013; Ucbasaran et al. 2008) and will attempt to receive a compensation for such investments (Rauch and Rijsdijk 2011). Becker (1964) also provided the widely accepted distinction between general and specific human capital. General human capital refers to knowledge and skills that are equally effective across contexts and situations. In other words, it is easily transferable across a variety of economic settings (Ucbasaran et al. 2008), since it is not directly related to a certain job (Rauch and Rijsdijk 2011). Conversely, specific human capital relates to knowledge and skills specific to a particular context (Gimeno et al. 1997). Therefore, it is of value only in certain contexts and situations, which implies that it has a narrower scope of applicability and is less transferable (Ucbasaran et al. 2008). Hence, while general human capital does not rely heavily on the context in which it is useful, specific human capital is, by definition, context specific. Accordingly, general human capital is typically acquired via formal education, whereas specific human capital is developed through experience (Estrin et al 2016; Unger et al. 2011). Indeed, experience and education are the two central attributes of human capital (Becker 1964).

Following this convention, the entrepreneurship literature has also considered these two sources of general and specific human capital among entrepreneurs, respectively: formal education and entrepreneurial experience (e.g. Baptista et al. 2014; Brüderl et al. 1992; Estrin et al. 2016; Rauch and Rijsdijk, 2011; Sexton and Upton 1985; Unger et al. 2011; Wiklund 
and Shepherd 2003). Formal education is seen as a form of general human capital while entrepreneurial experience is taken as a form of specific human capital. This is because general skills tend to be acquired via formal education and specific skills through start-up experience (Hessels et al. 2011; Unger et al. 2011). More specifically, while formal education provides knowledge and skills that can be useful not only for entrepreneurs and managers but also for other occupations and activities, knowledge and skills acquired by setting up and running a business (i.e. entrepreneurial experience) are valuable almost exclusively when the individual (i.e. entrepreneur) is engaged in the process of creating and running a new business.

With regard to entrepreneurial growth aspirations, past research has showed that general human capital, and more specifically higher education, has a positive effect on such aspirations (Autio and Acs 2010). However, to date no study has explored the impact of specific human capital attributes on entrepreneurial growth aspirations. In what follows, we argue that different human capital investments may lead to differences in growth aspirations.

\subsubsection{General human capital: educational attainment}

Educational attainment is likely to positively affect the growth aspirations of entrepreneurs for several reasons. First, individuals with higher levels of education may find entrepreneurship attractive but they are also more likely to be attractive to prospective employers (Lucas 1978). These individuals are even likely to be offered managerial jobs in wage employment (Estrin et al. 2016). Thus, because of their better job market prospects the opportunity cost of being involved in entrepreneurial activities increases for individuals with more educational attainment (Autio and Acs 2010). This accords with more educated entrepreneurs requiring higher growth potential of their ventures and, therefore, with the 
notion that if such individuals have decided to start up a business they will hold higher growth aspirations to compensate their higher opportunity cost.

In addition to the occupational choice argument, we suggest that formal education enable entrepreneurs to better recognize opportunities and to have better access to resources. More specifically, through formal education individuals acquire knowledge and skills that would allow them to gather, process, and analyze relevant information (Capelleras and Greene 2008; Forbes 2005; Kim et al. 2006). This knowledge gained through formal education may help them to learn about markets and technology and better recognize growth opportunities in the surrounding environment (Shane 2000). Therefore, higher levels of education may help entrepreneurs develop their skills to solve problems and make better decisions concerning business development (Baptista et al. 2014). Moreover, highly educated entrepreneurs may also have better social networks, as a result of their longer stay in the education system, which may be helpful for the development of their businesses (Ucbasaran et al. 2008). Prior work suggests that they tend to have access to a large and resource-rich network of contacts (Capelleras et al. 2010; Batjargal 2003) that favors their awareness of changes in the local environment, including the recognition and exploitation of good opportunities (Kibler et al. 2014), and the access to the resources they lack. All this may stimulate their willingness to grow the new business.

Hence, entrepreneurs will show more intentions to engage in growth oriented behaviors and more favorable assessments of the growth opportunities of their ventures as their level of educational attainment increases. They will also want to receive higher compensation for their human capital investment. This will be reflected in higher entrepreneurial growth aspirations. Formally, we hypothesize: 
Hypothesis 1 Entrepreneurial growth aspirations will be higher for individuals with higher educational attainment.

\subsubsection{Specific human capital: prior entrepreneurial experience}

Previous entrepreneurial experience, possibly the most distinctive form of entrepreneurial specific human capital, can be a strong predictor of growth aspirations. Unlike in the case of educational attainment, we expect experienced entrepreneurs to have less ambitious growth aspirations. Although individuals who invest more in their human capital are likely to strive for more growth in their firms because they want to receive higher compensation for their investment (Cassar 2006; Unger et al. 2011), experienced entrepreneurs may have lower aspirations for several reasons. First, in contrast to general human capital (i.e. formal education), specific entrepreneurial experience may entail lower opportunity costs vis-a-vis paid employment (Estrin et al. 2016). Since specific human capital in the form of prior entrepreneurial experience is not easily transferred to other contexts, it may not automatically be associated with higher expected returns in alternative employment opportunities (Rauch and Rijsdijk 2011). In fact, the know-how related to the starting and running of a business (e.g. being sensitive to opportunities and crafting business models to exploit them) is not necessarily valued in wage employment, which typically requires a specific domain expertise (e.g. operations, finance, marketing) (Estrin et al. 2016; Lazear 2005).

Secondly, prior entrepreneurial experience suggests learning in the context of the process of venture creation and development (Corbett 2005), as individuals with prior entrepreneurial experience have the opportunity to learn from mistakes and avoid them in future projects (Farmer et al. 2011). Enactive mastery, or the process of gaining knowledge by performing a task (Bandura 1997), is considered as the most influential source of efficacy information because it provides the most authentic evidence of whether one can muster what it takes to 
succeed. In this sense, entrepreneurs with previous entrepreneurial experience have first-hand information about the difficulties involved in growing a business and even surviving. ${ }^{1}$ Stiff competition and limited access to key resources are challenges that new firms that want to grow need to overcome (Gilbert et al. 2006). In this sense, experienced entrepreneurs may have experienced those difficulties and may be more aware than those without such experience of how hard the task of making the firm grow would be. With this knowledge, they may have a better idea of what needs to be done to realize growth. Therefore, individuals with entrepreneurial experience may have a more realistic view of the new venture growth process. This previous experience may thus mitigate the overconfidence that it is often attached to entrepreneurs (Koellinger et al. 2007).

Taking into account the previous arguments, it is likely that entrepreneurs with prior entrepreneurial experience would have lower expectations to succeed in the task of growing their firms up. This will be probably reflected also in more conservative, and maybe more realistic, predictions of their growth potential, that will jointly lead to lower growth aspirations. Formally stated:

Hypothesis 2 Entrepreneurial growth aspirations will be lower for individuals with prior entrepreneurial experience.

2.2 The moderating role of regional entrepreneurial culture

So far, we have hypothesized about the influence of individual human capital on the aspirations of entrepreneurs to grow their businesses. However, such aspirations are likely to be shaped by person-environment interactions (Autio and Acs 2010; Estrin et al. 2013). An institutional approach provides a robust foundation for investigating this person-in-situation

\footnotetext{
${ }^{1}$ According to the information provided by the Spanish National Institute of Statistics (Instituto Nacional de Estadística or INE) 55 to $60 \%$ of the firms created in a given year in Spain have disappeared in 5 years.
} 
argument (Bruton et al. 2010). Institutional economic and sociological theories argue that the behavior of individuals is affected by the rules and belief systems prevailing in the environment (Meyer and Rowan 1991; North 1990; Scott 2007). By conforming to these rules and beliefs, individuals and their organizations gain legitimacy and receive support, which contributes to survival (Bruton et al. 2010; DiMaggio and Powell 1983, 1991; Jepperson 1991; Scott 1995, 2007) and eventually to firm growth.

In the context of institutional theories, culture encapsulates the shared values and belief systems (Davidsson and Wiklund 1997; Foreman-Peck and Zhou 2013; Guiso et al. 2006; Jones 2006) that shape the environment in which human behavior (e.g. economic activities) is conducted. Therefore, culture is a central feature of the environment in which entrepreneurs are embedded. However, among the few attempts to explore the impact of the institutional environment on entrepreneurial growth aspirations (e.g. Estrin et al. 2013), only one study focused on culture. Using the GLOBE framework, Autio et al. (2013) analyzed the impact of national cultural practices on growth aspirations. Nevertheless, the regional cultural context appears to be particularly relevant when examining growth aspirations. Because of its proximity to the entrepreneur, certain regional cultural values have been shown to affect new firm formation at the regional level (Davidsson and Wiklund 1997; Kibler et al. 2014; Vaillant and Lafuente 2007). In the same token, these regional cultural norms can play a stronger role in affecting entrepreneurial growth aspirations, attitudes and behaviors than national contexts (Audretsch et al. 2016; Bosma and Schutjens 2011; Stuetzer et al. 2014).

In this study we suggest that a supportive regional entrepreneurial culture can strengthen the anticipated effect of an individual's human capital attributes on growth aspirations. Following prior research in this area, we focus on two core elements of a region's entrepreneurship culture. Huggins and Thompson (2016) acknowledge the importance of considering the legitimacy of entrepreneurship (Kibler et al. 2014) and the local 
entrepreneurial social capital (Westlund et al. 2014) when exploring the culture within particular places. Similarly, Fritsch and Wyrwich (2014) suggest that a regional entrepreneurial culture is linked to the transmission of entrepreneurial role models and the social acceptance of entrepreneurship, together with the existence of supporting services. In what follows, we pay attention to these two aspects and argue that both the social approval of entrepreneurship and entrepreneurial role models will positively moderate the previously advanced relationship between the entrepreneur's human capital (i.e. education and experience) and growth aspirations.

\subsubsection{Social acceptance of entrepreneurship}

The "legitimation" (Etzioni 1987) of entrepreneurs is considered a core element of a region's entrepreneurship culture (Freytag and Thurik 2007). The "regional social legitimacy of entrepreneurship", whose theoretical foundation is anchored in institutional theory (Kibler et al., 2014), refers to the perception that entrepreneurship is desirable or appropriate (Suchman 1995). This means that this occupational choice (i.e. entrepreneurship) is seen as a good career choice and being a successful entrepreneur is also seen as something positive (i.e. a socially legitimate activity). Kibler and Kautonen (2016) argue that the perceived moral legitimacy of entrepreneurship will influence social beliefs about what is desirable, which in turn affect the entrepreneurs' confidence in successfully managing their businesses. As such, we posit that growth aspirations of more educated and experienced entrepreneurs (i.e. general and specific human capital) will vary significantly depending on the regional social legitimacy of entrepreneurship.

More specifically, the existence of high levels of approval of entrepreneurship in a region (Wyrwich et al. 2016) may strengthen the perceived ability of entrepreneurs with higher levels of educational attainment to achieve firm growth, which in turn will spur their growth 
aspirations. In such a regional context, educated entrepreneurs will also have more access to the resources they need (from public organizations, business angels, venture capitalists, etc.) to successfully grow their businesses (Autio et al. 2013), also increasing their growth aspirations.

Similarly, a higher level of regional social legitimacy, which is associated with a less risky environment for entrepreneurship (Etzioni 1987), may also favor the access to resources and perceived ability to grow the business of experienced entrepreneurs, which would increase their confidence in navigating the challenges they expect to face in growing the new firm. Hence, if the level of acceptance of entrepreneurship is high, this would make it more feasible for experienced entrepreneurs to seek to grow their firms (Autio et al. 2013). Conversely, regional contexts where entrepreneurship is not socially legitimate or is not viewed as an acceptable behavior is likely to constrain the growth aspirations of more educated and experienced entrepreneurs.

In sum, we expect that the social acceptance of entrepreneurship in the region will positively affect the relationship between entrepreneurs' human capital attributes and growth aspirations. Entrepreneurs with greater educational attainment will further increase their positive growth perspectives, while those with prior entrepreneurial experience will hold a more positive view than in regions with lower social acceptance of entrepreneurship. Formally, we hypothesize:

Hypothesis 3a A high level of regional social acceptance of entrepreneurship will strengthen the positive impact of educational attainment on growth aspirations.

Hypothesis 3b A high level of regional social acceptance of entrepreneurship will attenuate the negative impact of prior entrepreneurial experience on growth aspirations. 


\subsubsection{Entrepreneurial role models}

Social relations and the corresponding networks are another key component of an entrepreneurial culture. Entrepreneurship research has long noted that social relationships with other, existing, entrepreneurs (i.e. entrepreneurial role models), are of capital importance to understand entrepreneurial decisions and performance (e.g. Bosma et al. 2012; Estrin et al. 2016; Gnyawali and Fogel 1994; Hmieleski and Corbett, 2006; Martin-Sanchez et al. 2017). The regional availability and visibility of entrepreneurs as a collective, societal, phenomenon may be considered as a resource at entrepreneur's disposal. Existing entrepreneurs may help the new ones to identify and acquire the skills, relationships and confidence needed for the expansion of their businesses (Contín-Pilart and Larraza-Kintana 2015; Estrin et al. 2016; Gnyawali and Fogel 1994). In addition, these established entrepreneurs may put in contact new entrepreneurs with a variety of external resource providers and, thus, help them to access the resources they need to grow (Korosteleva and Mickiewicz 2011). In this sense, contact with existing entrepreneurs gives new ones access to a key resource to support the growth of the new venture (Capelleras et al. 2011; Contín-Pilart and Larraza-Kintana 2015): first-hand advice.

Research has also shown that having access to existing entrepreneurs creates a network of role models that encourage entrepreneurial action, offer a supply of examples of how to be a successful entrepreneur (i.e. best practices) and provide access to both tangible and intangible (i.e. knowledge on how to achieve business growth) resources (Bosma et al. 2012; Gnyawali and Fogel 1994). In this vein, the contact and presence of other entrepreneurs in the region who have already achieved growth can foster local entrepreneurial learning processes, encouraging entrepreneurs' confidence of their abilities to also achieve firm growth, which will spur growth aspirations. A reasoning of the form: "If they can do it, I can do it too" 
(Sorenson and Audia 2000 p. 443) is more likely to occur when the entrepreneur is surrounded by other, successful, entrepreneurs.

Considering all the arguments above, our proposal is that regional entrepreneurial role models will positively moderate the impact of general and specific human capital upon growth aspirations. Specifically, entrepreneurs with higher educational attainment are more likely to have increasing aspirations due to the presence of such positive role models. These highly educated entrepreneurs will tend to increase their initial positive beliefs about the growth potential of their new ventures in regions with the presence of entrepreneurial role models, where established entrepreneurs put in hands of the new ones a variety of resources necessary to grow. Moreover, the expected negative relationship between prior entrepreneurial experience and growth aspirations is likely to be weakened if they can observe regional positive examples, since those observing successful entrepreneurs at work are less likely to fear entrepreneurial failure (Wyrwich et al. 2016). Experienced entrepreneurs can also take advantage of the learning opportunities and potential access to resources described above in a regional context in which entrepreneurial role modeling takes place. The presence of such role models in the social environment may thus reduce the ambiguity that entrepreneurs with prior start-up experience may feel about growing a business. Overall, we expect greater growth aspirations of highly educated and experienced entrepreneurs in regions with better, more dense, social networks of entrepreneurs. Formally stated:

Hypothesis 4a A high level of regional entrepreneurial role models will strengthen the positive impact of educational attainment on growth aspirations.

Hypothesis 4b A high level of regional entrepreneurial role models will attenuate the negative impact of prior entrepreneurial experience on growth aspirations. 
Figure 1 presents our model and summarizes the hypotheses.

Insert Figure 1 about here

\section{Methods}

\subsection{Data and sample}

In testing the hypotheses, we employ two levels of analysis-namely, individual and regional levels. More specifically, our empirical model combines unique annual harmonized primary data on early-stage individual entrepreneurial activity in Spain and secondary data consisting of information at the province level. Our analysis covers the years 2008 to 2014 . We must note at this point that we use cross-sectional data to test our hypotheses. Thus, the present study might suffer from an endogeneity problem. Following Stuetzer et al. (2014) and Estrin et al. (2016), we partly alleviate this issue by using time-lagged regional-level predictors. However, we cannot empirically model the relation of personal and regional characteristics and entrepreneurs' growth aspirations as cause and effect.

Individual observations are obtained from the Adult Population Survey (APS) of the Spanish Global Entrepreneurship Monitor (GEM) project. The APS is designed to obtain a representative sample of the Spanish population aged 18 to 64 . The APS includes different blocks of questions aimed at different types of respondents. For the purpose of this paper we focus on early-stage entrepreneurs that are those who own and manage a business that is less than 42 months old (Giotopoulos et al. 2016; Puente et al. 2016; Reynolds et al. 2005). By using this category, growth aspirations are obtained from firms that are at their initial stages of development (Douglas 2013; Estrin et al. 2013). After omitting observations for which there were any missing values and non-valid answers, we are left with a final sample of 1581 
entrepreneurs. Another block includes questions aimed at the whole population and, as shown later, allows us to measure their attitude toward entrepreneurship.

Regional variables were collected from the Spanish Statistics Institute (Instituto Nacional de Estadística, INE), EUROSTAT and the Spanish GEM data sets at the province level. The Spanish territory is divided into 52 provinces $^{2}$, which are the third-level territorial and administrative divisions "NUTS 3" under EUROSTAT classifications. We have confidence that the variables gathered from INE, EUROSTAT and the Spanish GEM data sets carefully capture the regional characteristics in our study.

\subsection{Variables and measures}

Dependent variable. In accordance with our conceptual model, the dependent variable is entrepreneurial growth aspirations. Following previous studies (e.g. Estrin et al. 2013), we calculate entrepreneurs' growth aspirations as the difference between (the natural logarithms of) the entrepreneurs expected number of employees in the next five years and the actual number of employees, exclusive of owners, at the firm's inception.

Individual-level predictors. To test our first two hypotheses on the relationship between general and specific human capital and entrepreneurial growth aspirations, we use the variables educational attainment and prior entrepreneurial experience, respectively. Educational attainment is measured in terms of years of schooling. Following the procedure described by Stuetzer et al (2014) we recoded the original categorical variable that reflected different educational categories in number of years of schooling needed to attain each category. In doing this, we obtain a more continuous variable that reflects entrepreneurs' educational attainment expressed in years. This is a more precise account of the investment of

\footnotetext{
${ }^{2}$ Because their high levels of population density, we omit 2 provinces corresponding to Ceuta and Melilla that are two independent cities geographically located in North Africa but that belong to the Kingdom of Spain. Their inclusion in the analyses does not affect our results and conclusions.
} 
individuals in formal education as changes from one level to the other are not constant, like in the original categorical variable, but reflect the minimum years of education that need to be invested to move from one level to the next. On the other hand, and based on previous research (e.g. Estrin et al. 2013; Wiklund and Shepperd 2003) we captured the respondent's prior experience creating and managing firms. This knowledge is costly to build and has an important tacit component (Dencker and Gruber 2014) that precludes other individuals to acquire it through investments in formal education. Entrepreneurial experience is a dummy variable that takes value 1 only for the entrepreneurs in the sample who already own and manage another established existing business (Estrin et al. 2013), beyond the current one, and which is older than 42 months. This variable is intended to measure entrepreneurial experience via previous start-up projects that entrepreneurs have developed.

Cross-level interactions. As explained before, two facets are central to understand and define the entrepreneurial culture of a region: social acceptance of entrepreneurship and the presence of entrepreneurial role models (Bosma et al 2012; Etzioni 1987; Fritsch \& Wyrwich 2014; Suchman 1995). Specifically, we proxy social acceptance of entrepreneurship with a variable that is equal to the proportion of individuals in the province who consider that starting a new business is a desirable career choice. The presence of entrepreneurial role models is measured as the proportion of individuals in the province who personally know an entrepreneur who started up in the last two years. The information was obtained from the responses provided by the APS of the GEM project. The individual level information was aggregated at the province level (Bosma and Sternberg 2014; Obschonka et al. 2013).

Consequently, to test hypotheses $3 \mathrm{a}, 3 \mathrm{~b}, 4 \mathrm{a}$ and $4 \mathrm{~b}$, we create the following four cross-level interaction variables: educational attainment $x$ social acceptance of entrepreneurship; entrepreneurial experience $x$ social acceptance of entrepreneurship; educational attainment 
$x$ entrepreneurial role models and entrepreneurial experience $x$ entrepreneurial role models. Both social acceptance of entrepreneurs and entrepreneurial role models are mean-centered before the calculation of the interaction terms (Aiken and West 1991).

Individual-level controls. We control for entrepreneur age in years (also in a quadratic form) and gender $(1=$ male, $0=$ female). Another relevant control variable, particularly in the Spanish context, is necessity entrepreneurship, which takes value 1 if the business was created by necessity or 0 if it was because of opportunity motivation (Bolívar-Cruz et al. 2014; Justo et al. 2015). Current employment level measures the number of employees at inception of the new business (not counting the owner), expecting a higher level of employment to be negatively related to growth aspirations of entrepreneurs (Estrin et al. 2013). Entrepreneurship training is measured by way of a dummy variable set equal to 1 if the entrepreneur has received some training activities related to starting and enterprise (and to 0 otherwise) (Capelleras et al. 2016). Perceived entrepreneurial skills controls for the entrepreneur's self-confidence perceptions derived from different forms of human capital (Giotopoulos et al. 2016; Stuetzer et al. 2014). It takes value 1 if the respondent perceives she has the knowledge, skills and experienced required to start-up a new business and 0 otherwise. Perceived founding opportunities is a measure of the entrepreneur's optimism (Cassar 2010). Specifically, it is a dummy variable set equal to 1 for entrepreneurs who perceived good opportunities to found a business within the next six months in the area where they live and 0 otherwise. We additionally control from household income. This categorical variable measures the entrepreneur's household income level within 7 different ranges of family incomes (detailed in table 1) (Giotopoulos et al. 2016; Stuetzer et al. 2014).

Regional-level controls. We control for a rich variety of regional characteristics. We have "objective" regional indicators (Kibler 2013), which are the main economic indicators 
available at provincial level in Spain, as well as other variables that capture more "soft" regional dimensions, which are intended to capture other aspects of the overall culture of the provinces. We also consider "spatial" regional indicators, which are proposed to adjust the model for potential spatial autocorrelation (Kibler 2013). The "objective" indicators are: population density measured as the number of inhabitants per square kilometer $\left(\mathrm{Km}^{2}\right)$ in each province and rounded to thousands. Provincial unemployment rates (in percentage) are published every three months, so we compute the yearly average unemployment rate as the average of the four quarters reported rates. We control for the annual unemployment rate change that is measured in terms of the change observed in the average unemployment rate from year $t-1$ to year $t$, it is divided by 100 for presentation purposes. The annual population rate change is based on the number of inhabitants in each province each year. As in the case of unemployment rates, the change is measured (in percentage) relative to the previous year's value. As stated, all these objective regional variables, except for population density, are lagged one year for endogeneity concerns. Additionally, the $G D P / c$ denotes the gross domestic product per capita in each province and is given (for presentation purposes) in thousands of euros.

The "soft" variables refer to two kernel dimensions of the overall culture of the province for which information available in Spain: engagement with education and collective action (Huggins and Thompson 2016). More specifically, engagement with education, which is considered to be an important culture feature of places (Tabellini 2010), is measured as the percentage of people aged 25-64 years with a tertiary education (post-secondary) degree. As indicator of collective action at a provincial level, we employ, following Huggins and Thompson (2016), the percentage of the population who voted to the right-of-center parties in the last national political elections (2011). We name this variable right voters. Those provinces with much of right-of-center voters would be less collectively oriented. 
Moreover, we have two variables that may be considered "ultimate manifestations" (Huggins and Thompson 2016) of the entrepreneurial culture at provincial level: stock of existing firms, measured as the numbers of firms in the province scaled by active population and entry rates, measured the as number of births of enterprises again scaled by active population. These two variables can be considered a "static" and a "dynamic" measure of entrepreneurship, respectively (Freytag and Thurik 2007).

The "spatial" regional variables are included to adjust for potential spatial autocorrelation. This may cause underestimation of standard errors and, therefore, may lead to unreliable significance estimators (Anselin and Rey 1991). Aiming to control for this potential issue, and following Kibler (2013), we have included the mean value of the residuals of the neighboring provinces in all our model estimations.

Finally, we include time dummies to enable controlling for the years of the pool—while excluding one (here, 2008) as a reference category. Industry controls are also included in all our specifications to account for sectorial differences on growth aspirations (Estrin et al. 2013). Tables 1 and 2 provide detailed definitions and descriptive statistics for individuallevel variables and regional-level ones, respectively.

Insert Tables $1 \& 2$ about here

\subsection{Methodological approach}

Our data set has a pooled cross-sectional time-series structure whereby individuals are hierarchically grouped by province. Because we are using two levels of analysis, data are analyzed using hierarchical linear modeling methods (Autio and Wennberg 2010; Autio et al. 2013; Bosma and Sternberg 2014; Estrin and Mickiewicz 2011; Estrin et al. 2013; Stuetzer et 
al. 2014). We do not employ standard multivariate methods because they would preclude us to assume the independence of observations (Autio and Wennberg 2010; Hofmann et al. 2000). In other words, those methods require to view individuals as acting homogenously but would not account for how the environment affects their decisions (Autio and Wennberg 2010). ${ }^{3}$

To estimate the direct effect of human capital endowments (i.e. educational attainment and entrepreneurial experience) on entrepreneurial growth aspirations, as well as the moderating effect of regions' entrepreneurship culture, we use a multilevel random effects specification (Autio et al. 2013; Estrin et al. 2013). Random effects analysis allows regression coefficients and intercepts to vary across provinces (Aguinis et al. 2011). In studies with more than one level of analysis, researchers have agreed that lower-level entities (e.g., individuals) are nested within higher-level ones (e.g., provinces) (Aguinis et al. 2013). This perspective has the advantage of facilitating multilevel analysis of cross-level interactions (Hundt and Sternberg 2014). In that sense, a multilevel random effects specification is more accurate than the multivariate methods (e.g., moderated multiple regressions) normally used in the management literature to estimate interaction effects (Aguinis et al. 2005).

We adopt a three-step strategy for testing the direct effect of human capital—and the moderating effect of entrepreneurial culture - on entrepreneurial growth aspirations. First, we devise a model with individual and province-level control variables (model 1 in table 4). Next, we add individual predictors (model 2 in table 4). Finally, we add cross-level interactions to estimate the moderating effect (models $3,4,5,6,7$ and 8 in table 4). The model we use to estimate both the direct effect of human capital endowments and the moderating effect of entrepreneurial culture on entrepreneurial growth aspirations takes the

\footnotetext{
${ }^{3}$ An alternative methodological approach to control for the effect of heterogeneity across groups is to estimate linear regression models taking into consideration the clustering of standard errors at the province level. It is worth noting that results using this alternative approach are fully consistent with the ones reported here.
} 
following form (Autio and Acs 2010; Autio et al. 2013; Snijders and Bosker 2004; Stuetzer et al. 2014).

Individual-level component

$$
\begin{aligned}
\log \left(\pi_{\mathrm{ij}}\right)_{\mathrm{t}}= & \beta_{0 \mathrm{j}} \\
& +\beta_{p j}\{\text { individual-level predictors } \mathrm{t}\} \\
& +\beta_{\mathrm{cj}}\{\text { individual-level controls } \mathrm{t}\} \\
& +\mathrm{r}_{\mathrm{ij}} .
\end{aligned}
$$

\section{$\underline{\text { Regional-level component }}$}

$\beta_{0 \mathrm{j}}=\gamma_{00}+\gamma_{01}\{$ regional-level controls $\mathrm{t}\}+\mu_{0 \mathrm{j}}$,

$\beta_{\mathrm{cj}}=\gamma_{\mathrm{p} 0}+\gamma_{\mathrm{p} 1}\{$ regional-level predictor $\mathrm{t}\}+\gamma_{\mathrm{p} 2}$ \{regional-level controls $\left.\mathrm{t}\right\}+\mu_{\mathrm{pj}}$.

In this model, $\pi_{\mathrm{ij}}$ is a continuous measure of the growth aspirations chosen by individual $i$ in region $j$. As we use the logarithm to normalize this measure, then $\beta_{0 \mathrm{j}}$ is the coefficient for the effect of each individual-hierarchically nested in a specific province-on growth aspirations. $\beta_{p j}$ and $\beta_{c j}$ are the coefficients for the individual-level variables in the model 2. The term $\gamma_{00}$ is the mean of all intercepts (sometimes called the "constant"; Autio and Wennberg 2010) across provinces, and $\gamma_{\mathrm{p} 0}$ is the mean of all slopes across provinces. We use $\gamma_{01}$ to signify the coefficients for regional-level variables in the model 2 ; similarly, $\gamma_{\mathrm{p} 1}$ and $\gamma_{\mathrm{p} 2}$ are coefficients for the cross-level variables in models 3, 4, 5, 6, 7 and 8. Individual and regional-level residuals capture the setup's random aspect; we use $\mathrm{r}_{\mathrm{ij}}$ for the individual-level residuals and $\mu_{0 \mathrm{j}}$ and $\mu_{\mathrm{pj}}$ for regional-level ones. In other words: the variation in $\mu_{0 \mathrm{j}}$ and $\mu_{\mathrm{pj}}$ quantify the degree of heterogeneity in intercepts across provinces, and the variation in $\mathrm{r}_{\mathrm{ij}}$ 
quantifies the within-group variance (Aguinis et al. 2013). In sum, regional characteristics could affect individual-level regressions because of variation, at the individual level, in the intercepts and/or slopes across provinces.

In addition, we estimate the variance inflation factors (VIF) for all our independent variables. All VIF values were within acceptable limits indicating that multicollinearity is not an issue in our analyses. All values were below 10 (Hair et al. 2006). In fact all variables except one province level control showed values below the strictest standard of 5 (Studenmund 1997). Specifically values ranged from 1.05 to 4.54 . In addition, tolerance values are all above 0.1 (including the variable with the higher VIF), which further indicates that our variables do not suffer from multicollinearity (Autio et al. 2013).

\section{Results}

\subsection{Descriptive results}

Table 1 and table 2 provide descriptive statistics, and table 3 displays the correlations for all the variables included in this analysis. The average age of the respondents in the sample of early-stage entrepreneurs is almost 40 years and $60 \%$ of them are men. Most of them $(66 \%$ of the sample) do not view good opportunities to set up a new venture in the area where they live in the next six months. This may be due to the economic downturn that the Spanish economy suffered during our period of analysis. The overwhelming majority (89\%) of entrepreneurs think that they have the knowledge, skills and experience required to start-up and $44 \%$ of them have received entrepreneurship training. About one fifth of them indicate that their entrepreneurial activity is driven by necessity. The average number of current employees and household income are 2.41 and 3.20 , respectively. 
With regard to human capital variables table 1 shows that the average investment of formal education is around 14.88 years. Additionally, entrepreneurs who had previous entrepreneurial experience represent the $7 \%$ of the sample.

Turning to the regional variables, the average population density is 276.51 inhabitants per $\mathrm{km}^{2}$. The unemployment rate increased (on average) $22 \%$ annually at the provincial level, which reveals how hard the Spanish economy was hit by the economic crisis. The annual population change is about $0.53 \%$ inhabitants, and the average GDP per capita (all provinces) is about $€ 23,100$. Around $53 \%$ of population voted to right or center parties in the last general election in Spain and 30\% have tertiary education. The percentage of existing firms over the total active population is, on average, 15.19 and the entry rate 1.22.

At the national level $33 \%$ of respondents of the APS survey state that they personally know at least an entrepreneur who started a venture within the last two years. $62 \%$ of the adult population in Spain thinks that starting a new business is a desirable career choice, showing that, on average, social acceptance of entrepreneurship seems to be high in Spain. Nonetheless, variation exists in these two variables across the 50 provinces considered in the study, creating more or less favorable entrepreneurial environments.

Insert Table 3 about here

4.2 Multilevel model results

Table 3 shows the bivariate correlations of all the variables considered in this paper and Table 4 reports results from multilevel random intercept models predicting entrepreneurial growth aspirations. As indicated, model 1 provides results for the individual and regionallevel control variables. Model 2 incorporates the effects of the individual predictors (i.e. 
educational attainment and prior entrepreneurial experience). Then, model 3 and 4 add the interactions between the generic and the specific human capital and the social acceptance of entrepreneurship, respectively and model 5 incorporate both. Models 6 and 7 add the interactions between the generic and the specific human capital and the entrepreneurial role models, respectively and model 8 finally incorporates both. To test our hypotheses, we focus mainly on models 5 and 8 (most general specifications). However, it is worth noting that results of the other models are in line with those observed in such models.

In support of hypotheses 1 and 2, across all models education and entrepreneurial experience are positively and negatively related, respectively, with growth aspirations. Model 3 does not support hypothesis $3 \mathrm{a}$ as the positive effect of observed educational attainment does not vary with the increments in the levels of social acceptance of entrepreneurship. This result is also observed in the full model 5 . In line with hypothesis $3 \mathrm{~b}$, in model 4 we find that the negative effect of entrepreneurial experience will be attenuated as the levels of social acceptance of entrepreneurship increase in the region, a result that holds consistent in model 5. In fact, once this interaction is taking into consideration the overall effect of prior entrepreneurial experience turns to be positive, which in other words means that the negative influence of entrepreneurial experience on growth aspirations will be attenuated when the social acceptance of entrepreneurship in the province is higher.

\section{Insert Table 4 about here}

Model 6 supports hypothesis 4a suggesting that the positive effect of observed educational attainment varies with higher levels of regional entrepreneurial role models. This result keeps consistent in model 8. Thus, evidence supports that the positive effect of educational attainment on growth aspirations will be higher when the presence of regional entrepreneurial 
role models increases. In line with hypothesis $4 \mathrm{~b}$, we find in model 7 that the negative effect of entrepreneurial experience will be attenuated as the levels of regional entrepreneurial role models increase. In fact, as it was reported in the case of social acceptance of entrepreneurship, the negative effect of entrepreneurial experience turns to be positive when the interaction term is taking into account.

To better gauge the net effects of the statistically significant interaction terms we next present the corresponding interaction plots. Figures 2 and 4 depict the interaction effects of prior entrepreneurial experience and (respectively) social acceptance of entrepreneurship and regional entrepreneurial role models on entrepreneurial growth aspirations. Alternatively, figure 3 describes the interaction effect of educational attainment and regional entrepreneurial role models. Observe that, consistently with our prediction, the relationship between entrepreneurial experience and growth aspirations changes with the social acceptance of entrepreneurship and the effect of entrepreneurial role models. In particular, in figure 2 growth aspirations of entrepreneurs with prior entrepreneurial experience are higher when the social acceptance of entrepreneurship is higher as well. In the same direction, in figure 4 we can see that growth aspirations of entrepreneurs with prior entrepreneurial activity are also higher when the levels of regional entrepreneurial role models in the province are higher too. Furthermore, regarding to the effect of educational attainment, we find that growth aspirations of entrepreneurs with higher educational attainment levels are intensified when the levels of regional entrepreneurial role models in the province are also high.

Insert Figures $2 \& 3$ about here

We find several control variables to be statistically significant. Not surprisingly, entrepreneurs who are younger, those that see good opportunities for starting a business in the 
area where they live, and those who believe they have the knowledge, experience and skills to start-up a new venture have higher growth aspirations. Also, those businesses with higher levels of employment at inception will tend to have lower growth aspirations (Estrin et al., 2013). As per the regional context, GDP per capita has a negative effect on aspirations, a result that has been previously reported in the literature and is consistent with the view that high growth opportunities for entrepreneurs are available in developing economies and regions (Estrin et al. 2013).

\subsection{Robustness tests}

Given that growth aspirations are observed only for those individuals who have been identified as early stage entrepreneurs, it could be that self-selection into entrepreneurship has biased our findings. In other words, there might be unobservable characteristics of the individual (e.g. ability, motivation, (risk) preferences) that influenced her decision to become an entrepreneur, which might be also correlated with her growth aspirations afterwards. Neglecting this potential self-selection bias may produce unreliable estimates.

To address this issue, we apply a two-step Heckman selection model as follows. First, we estimate the probability of entering entrepreneurship (the first-stage or "selection" equation). As an exclusion restriction, we include in this equation a variable that is correlated with the decision of entering entrepreneurship, yet uncorrelated with the outcome variable of interest (growth aspirations). Specifically, we use a variable that captures the entrepreneur's media environment, which in GEM data corresponds to a dummy variable indicating how often the individual sees in her region coverage in the public media about successful new business cases. The validity of this exclusion restriction is confirmed by our further analysis. Second, we estimate the growth aspirations equation (the second-stage or "outcome" equation) and introduce in the set of regressors the Inverse Mills Ratio obtained from the estimation of the 
first stage. We do not detect any significant selection bias arising from the possibility that the unobservable factors determining the decision to become an entrepreneur also determine the entrepreneur's employment growth aspirations. Accordingly, the conclusions from our hypothesis testing do not change once we address potential biases caused by individuals' selfselection into entrepreneurship (see also Autio et al. 2013; Estrin et al. 2013).

\section{Discussion}

Understanding how entrepreneurs develop their beliefs about firm growth is an important topic in the entrepreneurship literature (Wright and Stigliani 2013). In fact, the decision to grow their new ventures is a strategic decision that has long-lasting implications for subsequent performance (Gilbert et al. 2006). This study contributes to improve our knowledge about the formation of entrepreneurial growth aspirations by addressing for the first time the differential influence of entrepreneur's general and specific human capital and exploring how regional entrepreneurial culture, a factor not previously considered, moderates the link between human capital and growth aspirations.

Prior studies in this area have examined individual and institutional determinants of growth aspirations at the country level (Autio and Acs 2010; Estrin et al. 2013). Our paper extends prior research to show not only the tight connection between the human capital of entrepreneurs and their growth aspirations, but also that this connection depends on the regional entrepreneurial culture. The link between culture and entrepreneurship is not new in the literature (Obschonka et al. 2015; Stuetzer et al. 2014) but here we have considered the moderating effects of the regional culture on ambitious entrepreneurship, specifically on entrepreneurial growth aspirations.

The study also responds to calls for studies combining measures from multiple levels of analysis when exploring high growth entrepreneurship to simultaneously explore the 
influence of personal and contextual variables (Hermans et al. 2015). We have used a rich data set that combines individual data on early-stage entrepreneurs taken from the Spanish GEM project with regional data from the Spanish Statistic Institute, EUROSTAT and GEM.

\subsection{Human capital effects on growth aspirations}

Our first main finding is that the effect of general and specific human capital is different: growth aspirations are higher for individuals with higher educational attainment and lower for individuals with prior entrepreneurial experience. This evidence supports the argument that individuals who invest more in their general human capital (i.e. formal education) strive for higher firm growth not only because they want to receive a higher compensation from their investment (Autio and Acs 2010; Cassar 2006) but also because they tend to have more favorable assessments of the growth opportunities of their new ventures. In contrast, experienced entrepreneurs tend to have lower aspirations because they have lower opportunity costs than highly educated individuals and also because they have first-hand valuable information concerning the difficulties and prospects of new ventures. This is a novel contribution of our study as previous research on the effect of human capital on growth aspirations focused only on the implications of formal education (i.e. general human capital) (Autio and Acs 2010).

An implication that can be derived from this finding is that it is important to consider how specific and general human capitals affect the aspiration to grow the business. Our analysis points to the need of considering heterogeneity in the effects of human capital on growth aspirations, which is in line with recent studies on the human capital-entrepreneurship link (Estrin et al. 2016). As such, we show that educational attainment and prior entrepreneurial experience lead to different effects on aspirations. In this vein, our model offers an additional explanation based on learning considerations, in addition to the more usual occupational 
choice argument. In this respect, we have considered that entrepreneurs with prior start-up experience may have a more realistic view of the difficulties involved in growing a business. This is important as it opens the floor for more research on the learning processes that shape entrepreneurs minds, which also points to further investigation on the cognitive mechanisms that lead to the formation of entrepreneurial growth aspirations (Douglas 2013; Wiklund and Shepherd 2003).

5.2. The moderating influence of the regional cultural context

The second main finding of our research is that the impact of human capital attributes can be moderated by cultural elements of the regional context. The study shows that individuals with previous entrepreneurial experience in regions with higher social acceptance of entrepreneurship and entrepreneurial role models tend to increase their growth aspirations. Therefore, while these individuals are less ambitious in general, as compared to the rest of entrepreneurs, they increase their aspirations to grow in areas where the attractiveness of entrepreneurship as a career option is higher and where the chances of observing and interacting with other entrepreneurs are high. Hence, our results suggest that regions with strong entrepreneurial cultures encourage the pursuit of growth by those individuals who have already had experience in setting up a business. These findings are in line with previous studies that have found a moderating (Kibler et al. 2014) or indirect (Stuetzer et al. 2014) effect of regional features on the relationship between entrepreneurs' characteristics and subsequent intentions; but we add to this literature an explanation of their role in influencing growth aspirations. The implication here is that those regional environments that favor entrepreneurial intentions and enable individuals to observe and interact with entrepreneurs provide a mechanism that reinforces the link between specific human capital and growth aspirations. In effect, our analysis reveals that the transmission of entrepreneurial role models 
and social acceptance of entrepreneurship are likely not only to have direct positive effects on the level of entrepreneurial activity, as shown by previous studies (e.g. Fristch and Wyrwich 2014) but also act as moderators in the relationship between entrepreneurs' experience and growth aspirations.

In contrast, we found that growth aspirations of individuals having superior educational attainment are not necessarily affected in the same way by those features of the regional entrepreneurial culture. Specifically, our analyses confirm the predicted positive moderating effect of entrepreneurial role models in the relationship between education and aspirations, but not in the case of the social acceptance of entrepreneurship. Therefore, the presence of role models in a region constitute a socio-cultural force that influences highly educated entrepreneurs, whereas the approval of entrepreneurship does not seem to have any direct or indirect effects on their growth aspirations. This points to a more complex dynamic in the case of general human capital than the one observed in the case of specific human capital, and further reinforces the need, stressed in this article, of distinguishing between these two types of human capital endowments. It also points to the importance of role models for highly educated entrepreneurs, which is in line with the propositions and evidence provided by Bosma et al. (2012). In this sense, the presence of role models in university classrooms may be an effective tool to shape the growth ambitions of future entrepreneurs. Yet, care should be taken not to spur overconfidence biases that may result in wrong investment decisions (Koellinger et al. 2007). With regard to the lack of a moderating effect of the social approval of entrepreneurship, it can be interpreted in terms of the rising opportunity costs of highly educated entrepreneurs, since they are likely to be offered good jobs in wage employment irrespective of the entrepreneurial culture of the region. This may also be because these individuals have a broader knowledge base which enables them to adapt to different 
situations more easily than others (Lazear 2005) and, therefore, their growth aspirations are less influenced by variations in the environment that surrounds them.

\subsection{Policy implications and future research}

Our findings about the importance of both human capital attributes and regional entrepreneurial culture in explaining high growth entrepreneurship have a number of policy implications. Increasing the proportion of highly educated individuals might favor the establishment of new business with high aspirations, even in adverse economic conditions (Giotopoulos et al, 2016). Nonetheless, care should be called upon not to feed over-optimistic or unrealistic growth expectations that could lead to suboptimal investment policies by entrepreneurs. In this sense, greater interaction between entrepreneurs with and without prior entrepreneurial experience may be an effective tool to motivate growth ambitions in the former and give first hand business information to the later. Public policy initiatives aimed at encouraging professional networks or contacts may also help to indirectly increase growth aspirations. Additionally, entrepreneurial culture can be understood as a resource for regions to enhance the ambitions of experienced entrepreneurs. Thus, another policy implication is that some of the resources devoted to business support initiatives can be focused to promote positive entrepreneurial role models and the social legitimacy of entrepreneurship. However, it should be noted that encouraging certain norms and values may not be so simple, given the stability of culture (Stephan and Uhlaner 2010). Public authorities should therefore consider this as a long term investment effort.

This study is not free of limitations, which nonetheless open opportunities for relevant future research. Our research is based on data for a single country. A useful extension would be to test our conceptual model on the determinants of growth aspirations with data from other countries. And notwithstanding the value of examining cross-level interactions among factors 
at the individual and regional level, future research should extend this approach by incorporating national-level determinants.

The binary character of some of our key variables may also be considered a limitation. Dichotomous variables in large questionnaires such as that used in the GEM project are often included to simplify data gathering process and subsequent coding. The need for simplicity is reinforced by GEM's global character: binary scales help minimize bias due to cultural interpretations (Autio et al. 2013) and reduce problems of translation equivalence (Ter Hofstede et al. 2002). However, interesting insights would be gained if future research accounts for the nature of higher education and for other types of experience, particularly industry experience. Measuring entrepreneurial culture using the macro-psychological makeup of regions (Obschonka et al. 2015) would also be necessary for future studies on the determinants of entrepreneurial growth aspirations.

As indicated in the methods section, our data has a strong cross-sectional character. While some of the province level variables were lagged to capture some causal dynamics, individual level variables were cross sectional. Nevertheless, this pooled sample allowed us to run our analyses with a large number of observations that span a seven year period. Very interesting insights could be gained in the future if panel data sets are created containing information on growth aspirations over time. How those aspirations change and adjust, for as a function of realized past performance, is certainly an exciting research question. Research on this topic could benefit from the large literature on the strategic management field that has studied the influence of performance feedback on strategic decision making (e.g. Greve 2010).

An interesting line for future research that would complement the individual-environment research and that remains relatively unexplored relates to the interplay of the different environmental characteristics. In this study we have considered that social acceptance of 
entrepreneurship and the existence of entrepreneurial role models as two separate elements. However, they, as well as other environmental factors, are intertwined. For example, it could be argued that patterns of agglomeration may influence perceptions and beliefs, and have a say in the entrepreneurial culture of the region. How do these different regional variables interact to determine entrepreneurial though and actions? Are they complements or their effects are largely independent?

\subsection{Conclusion}

This paper has analyzed and documented for the first time how growth aspirations of entrepreneurs tend to vary depending on different forms of individual human capital and how this link might differ according to the regional entrepreneurial cultural context in which the individual is embedded. In doing so, our study extends human capital theory to show that education and experience have differing effects on entrepreneurial growth aspirations. The paper also enriches existing research on regional entrepreneurship by adding an important but previously neglected contextual moderating factor (regional entrepreneurial culture) to the relationship between human capital and growth aspirations.

\section{References}

Aguinis, H., Beaty, J. C., Boik, R. J., \& Pierce, C. A. (2005). Effect size and power in assessing moderating effects of categorical variables using multiple regression: A 30-year review. Journal of Applied Psychology, 90, 94-107.

Aguinis, H., Gottfredson, R. K., \& Wright, T. A. (2011). Best-practice recommendations for estimating interaction effects using meta-analysis. Journal of Organizational Behavior, 32, 1033-1043.

Aguinis, H., Gottfredson, R. K., \& Culpepper, S. A. (2013). Best-Practice Recommendations for Estimating Cross-Level Interaction Effects Using Multilevel Modeling. Journal of Management, 39(6), 1490-1528. 
Aiken, L. S., \& West, S. G. (1991). Multiple regression: Testing and interpreting interactions. Newbury Park, London, Sage.

Anselin, L., \&Rey, S. (1991). Properties of tests for spatial dependence in linear regression models. Geographical Analysis, 23: 112-130.

Audretsch, D. B., Obschonka, M., Gosling, S.D., \& Potter, J. (2016). A new perspective on entrepreneurial regions: linking cultural identity with latent and manifest entrepreneurship. Small Business Economics, DOI 10.1007/s11187-016-9787-9.

Autio, E., \& Acs, Z. (2010). Intellectual property protection and the formation of entrepreneurial growth aspirations. Strategic Entrepreneurship Journal, 4, 234-251.

Autio, E., \& Wennberg, K. (2010). You think, therefore, I become: Social attitudes and the transition to entrepreneurship. Presented at the DRUID summer conference, London, June $16-18$.

Autio, E., Pathak, S., \& Wennberg, K (2013). Consequences of cultural practices for entrepreneurial behaviors. Journal of International Business Studies, 44, 334-362.

Bandura, A. (1997). Self-efficacy: The exercise of control. New York: Freeman.

Baptista, R., Karaöz, M., \& Mendonça, J. (2014). The impact of human capital on the early success of necessity versus opportunity-based entrepreneurs. Small Business Economics, 42(4), 831-847

Batjargal, B. (2003). Social capital and entrepreneurial performance in Russia: A longitudinal study. Organization Studies, 24, 535-556.

Baum, J. R., Locke, E. A., \& Smith, K. G. (2001). A multidimensional model of venture growth. Academy of Management Journal, 44(2), 292-303.

Becker, G. S. (1964). Human capital. Chicago: University of Chicago Press.

Beugelsdijk, S. (2007). Entrepreneurial culture, regional innovativeness and economic growth. Journal of Evolutionary Economics, 17, 187-210.

Bolívar-Cruz, A., Batista-Canino, R. M., \& Hormiga, E. (2014). Differences in the perception and exploitation of entrepreneurial opportunities by immigrants. Journal of Business Venturing Insights, (1-2), 31-36.

Bosma, N., \& Schutjens, V. (2011). Understanding regional variation in entrepreneurial activity and entrepreneurial attitude in Europe. The Annals of Regional Science, 47, 711742.

Bosma, N., Hessels, J., Schutjens, V., van Praag, M., \& Verheul, I. (2012). Entrepreneurship and role models. Journal of Economic Psychology, 33, 410-424. 
Bosma, N., \& Sternberg, R. (2014). Entrepreneurship as an Urban Event? Empirical Evidence from European Cities. Regional Studies, 48, 1016-1033.

Brüderl, J., Preisendorfer, P., \& Ziegler, R. (1992). Survival Chances of Newly Founded Business Organizations. American Sociological Review, 57(2), 227-242.

Bruton, G.D., Ahlstrom, D., \& Li, H.L. (2010). Institutional theory and entrepreneurship: Where are we now and where do we need to move in the future? Entrepreneurship Theory and Practice, 34(3), 421-440.

Capelleras, J.L., \& Greene, F.J. (2008). The determinants and growth implications of venture creation speed. Entrepreneurship and Regional Development, 20(4), 311-337.

Capelleras, J.L., Greene, F.J., Kantis, H., \& Rabetino, R. (2010). Venture creation speed and subsequent growth: Evidence from South America. Journal of Small Business Management, 48(3), 302-324.

Capelleras, J.L., Contín-Pilart, I., \& Larraza-Kintana, M. (2011). Publicly funded prestart support for new firms: who demands it and how it affects their employment growth. Environment and Planning C: Government and Policy, 29, 821-847.

Capelleras, J.L, Contín-Pilart, I., Larraza-Kintana, M., \& Martin-Sanchez, V. (2016). Unemployment and growth aspirations: the moderating role of education. Strategic Change, 25, 169-183.

Cassar, G. (2006). Entrepreneur opportunity costs and intended venture growth. Journal of Business Venturing, 21(5), 610-632.

Cassar G. (2010). Are individuals entering self-employment overly optimistic? An empirical test of plans and projections on nascent entrepreneur expectations. Strategic Management Journal, 31, 822-840.

Contín-Pilart, I., \& Larraza-Kintana, M. (2015). Do entrepreneurial role models influence the nascent entrepreneurial activity of immigrants? Journal of Small Business Management, 53(4), 1146-1163.

Corbett, A. C. (2005). Experiential learning within the process of opportunity identification and exploitation. Entrepreneurship: Theory and Practice, 29(4), 473-491.

Davidsson, P., \& Wiklund, J. (1997). Values, beliefs and regional variations in new firm formation rates. Journal of Economic Psychology, 18 (2-3), 179-199.

Davidsson, P., Achtenhagen, L., \& Naldi, L. (2006). What do we know about small firm growth? In Parker, S. (Ed.), The life cycle of entrepreneurial ventures. New York: Springer, 361-398. 
Dencker, J.C., \& Gruber, M. (2014). The effects of opportunities and founder experience on new firm performance. Strategic Management Journal, 36, 1035-1052.

DiMaggio, P.J., \& Powell, W.W. (1983). The iron cage revisited: Institutional isomorphism and collective rationality in organizational fields. American Sociological Review, 48, 147160 .

DiMaggio, P.J., \& Powell, W.W. (1991). Introduction. In W.W. Powell \& P.J. DiMaggio (Eds.), The new institutionalism in organizational analysis (pp. 1-38). Chicago: University of Chicago Press.

Douglas, E. J. (2013). Reconstructing entrepreneurial intentions to identify predisposition for growth. Journal of Business Venturing, 28, 633-651.

Estrin, S., \& Mickiewicz, T. (2011). Institutions and female entrepreneurship. Small Business Economics, 37 (4), 397-415.

Estrin, S., Korosteleva, J., \& Mickiewicz, T. (2013). Which institutions encourage entrepreneurial growth aspirations? Journal of Business Venturing, 24(4): 564- 580.

Estrin, S., Mickiewicz, T., \& Stephan, U. (2016). Human capital in social and commercial entrepreneurship. Journal of Business Venturing, 31, 449-467.

Etzioni, A. (1987). Entrepreneurship, adaptation and legitimation. Journal of Economic Behaviour and Organization, 8, 175-189.

Farmer, S., Yao, X., \& Kung-McIntyre, K. (2011). Social roles, identities, and entrepreneurship: a three-nation study in the US, China, and Taiwan. Entrepreneurship Theory and Practice, 35, 245-273.

Forbes, D. (2005). Managerial determinants of decision speed in new ventures. Strategic Management Journal, 26, 355-366.

Foreman-Peck, J., \& Zhou, P. (2013). The strength and persistence of entrepreneurial cultures. Journal of Evolutionary Economics, 23, 163-187

Freytag, A., \& Thurik, R. (2007). Entrepreneurship and its determinants in a cross country setting. Journal of Evolutionary Economics, 17(2), 117-31.

Fritsch, M., \& Wyrwich, M. (2014). The long persistence of regional levels of entrepreneurship: Germany, 1925-2005. Regional Studies, 48(6), 955-973.

Gilbert B. A., McDougall P.M., \& Audretsch D. B. 2006. New venture growth: A review and extension. Journal of Management, 32(6), 926-950.

Gimeno, J., Folta, T., Cooper, A., \& Woo, C. (1997). Survival of the fittest? Human entrepreneurial capital and the persistence of firms. Administrative Science Quarterly, 
42(4), 750-783.

Giotopoulos, I. Kontolaimou, A., \& Tsakanikas, A. (2016). Drivers of high-quality entrepreneurship: what changes did the crisis bring about? Small Business Economics, DOI 10.1007/s11187-016-9814-x.

Gnyawali, D. R., \& D. S. Fogel (1994). Environments for Entrepreneurship Development: Key Dimensions and Research Implications. Entrepreneurship Theory and Practice, 18, $43-62$.

Greve, H.R. (2010). Positional rigidity: low performance and resource acquisition in large and small firms. Strategic Management Journal, 32, 103-114.

Guiso, L., Sapienza, P., \& Zingales, L. (2006). Does culture affect economic outcomes? Journal of Economic Perspective, 20 (2), 23-48.

Hair, J.F., Black, B., Babin, B., Anderson, R.E., \& Tatham, R.L. (2006). Multivariate Data Analysis 6th ed. Prentice Hall, Upper Saddle River, NJ.

Hermans, J., Vanderstraeten, J., van Witteloostuijn, A., Dejardin, M., Ramdani, D., \& Stam, E. (2015). Ambitious entrepreneurship: A review of growth aspirations, intentions, and expectations. Entrepreneurial Growth: Individual, Firm, and Region, 17, 127-160.

Hessels, J., Grilo, I., Thurik, R., \& van der Zwan, P. (2011). Entrepreneurial exit and entrepreneurial engagement. Journal of Evolutionary Economics 21(3), 447-471.

Hmieleski, K.M., \& Corbett, A.C. (2006). Proclivity for improvisation as a predictor of entrepreneurial intentions. Journal of Small Business Management, 44(1), 45-63.

Hofmann, D. A., Griffin, M. A., \& Gavin, M. B. (2000). The application of hierarchical linear modeling to organizational research. In Klein, K. J. \& Kozlowski, S. W. J. (Eds.). Multilevel Theory, Research, and Methods in Organizations: Foundations, Extensions, and New Directions. San Francisco: Jossey-Bass, pp: 467-511.

Huggins, R., \& Thompson, P. (2016). Socio-Spatial Culture and Entrepreneurship: Some Theoretical and Empirical Observations. Economic Geography, 92(3), 269-300.

Hundt, C., \& Sternberg, R. (2014). Explaining new firm creation in Europe from a spatial and time perspective: A multilevel analysis based upon data of individuals, regions and countries. Papers in Regional Science, 95(2), 223-257.

Jepperson, R. (1991). Institutions, institutional effects, and institutionalism. In W.W. Powell \& P.J. DiMaggio (Eds.), The new institutionalism in organizational analysis (pp. 143163). Chicago: University of Chicago Press. 
Jones, E.L. (2006). Cultures merging: a historical and economic critique of culture. Princeton University Press, Princeton.

Justo, R., DeTienne, D. R., \& Sieger, P. (2015). Failure or voluntary exit? Reassessing the female underperformance hypothesis. Journal of Business Venturing, 30(6), 775-792.

Kibler, E. (2013). Formation of entrepreneurial intentions in a regional context. Entrepreneurship and Regional Development, 35(3-4), 293-323.

Kibler, E., Kautonen, T., \& Fink, M. (2014). Regional social legitimacy of entrepreneurship: Implications for entrepreneurial intention and start-up behavior. Regional Studies, 48 (6), 995-1015.

Kibler, E., \& Kautonen, T. (2016). The moral legitimacy of entrepreneurs: An analysis of early-stage entrepreneurship across 26 countries. International Small Business Journal, 34(1), 34-50.

Kim, P. H., Aldrich, H. E., \& Keister, L. A. (2006). Access (not) denied: The impact of financial, human, and cultural capital on entrepreneurial entry in the United States. Small Business Economics, 27(1), 5-22.

Koellinger, P., Minniti, M., \& Schade, C. (2007). I think I can, I think I can...: a study of entrepreneurial behavior. Journal of Economic Psychology, 28, 502-527.

Korosteleva, J., \& Mickiewicz, T., (2011). Start-up finance in the age of globalisation. Emerging Markets Finance and Trade, 47(3), 23-49.

Lazear, E., (2005). Entrepreneurship. Journal of Labor Economics, 23, 649-680.

Levie, J., \& Autio, E. (2013). Growth and growth intentions. Enterprise Research Centre White Paper.

Lucas, J. R. E. (1978). On the size distribution of business firms. The Bell Journal of Economics, 508-523.

Martin-Sanchez, V., Contín-Pilart, I., \& Larraza-Kintana, M (2017). The influence of entrepreneurs'social referents on start-up size. International Entrepreneurship and Management Journal. DOI 10.1007/s11365-017-0454-7.

Marvel, M. R. (2013). Human capital and search-based discovery: a study of high-tech entrepreneurship. Entrepreneurship Theory and Practice, 37(2), 403-419.

Meyer, J. W., \& Rowan, B. (1991). Institutionalized organizations: Formal structure as myth and ceremony. In W.W. Powell \& P.J. DiMaggio (Eds.), The new institutionalism in organizational analysis (pp. 41-62). Chicago: University of Chicago Press.

Mincer, J. (1958). Investment in human capital and personal income distribution. Journal of 
Political Economy, 66, 281-302.

North, D. C. (1990). Institutions, institutional change and economic performance. New York: Cambridge. University Press.

Obschonka, M., Schmitt-Rodermund, E., Silbereisen, R.K., Gosling, S.D., \& Potter, J. (2013). The regional distribution and correlates of an entrepreneurship-prone personality profile in the United States, Germany and the United Kingdom: a sociecological perspective. Journal of Personality and Social Psychology, 105, 104-122.

Obschonka, M., Stuetzer, M., Gosling, S. D., Rentfrow, P. J., Lamb, M. E., Potter, J., \& Audretsch, D. B. (2015). Entrepreneurial regions: Do macro-psychological cultural characteristics of regions help solving the "knowledge paradox" of economics? PLoS ONE, 10, e0129332. doi:10.1371/journal.pone.0129332.

Puente, R., Cervilla, M. A., González, C. G., \& Auletta, N. (2016) Determinants of the growth aspiration: a quantitative study of Venezuelan entrepreneurs. Small Business Economics, 1-28. doi:10.1007/s11187-016-9791-0.

Rauch, A., \& Rijsdijk, S.A. (2013). The effects of general and specific human capital on long-term growth and failure of newly founded businesses. Entrepreneurship Theory and Practice, 37(4): 923-941.

Reynolds, P., Bosma, N., Autio, E., Hunt, H., De Bono, N., Servais, I., Lopez-Garcia, P., \& Chin, N. (2005). Global Entrepreneurship Monitor: Data Collection Design and Implementation 1998-2003. Small Business Economics, 24, 205-231.

Schultz, T. W. (1961). Investment in human capital. American Economic Review, 51(1), 117.

Scott, W.R. (1995). Institutions and organizations. Thousand Oaks, CA: Sage Publications.

Scott, W.R. (2007). Institutions and organizations: Ideas and interests. Thousand Oaks, CA: Sage Publications.

Sexton, D.L., \& Upton, N.B. (1985). The entrepreneur: a capable executive and more. Journal Business Venturing, (1), 129-140.

Shane, S. (2000). Prior knowledge and the discovery of entrepreneurial opportunities. Organization Science, 11(4): 448-469.

Snijders, T.A.B., \& Bosker, R.J. (2004). Multilevel analysis: An introduction to basic and advanced multilevel modeling. London: Sage. 
Sorenson, O., \& Audia, P. G. (2000). The social structure of entrepreneurial activity: Geographic concentration of footwear production in the United States, 1940-1989. American Journal of Sociology, 106(2), 424-462.

Stephan, U., \& Uhlaner, L. (2010). Performance-based vs socially supportive culture: A cross-national study of descriptive norms and entrepreneurship. Journal of International Business Studies, 41, 1347-1364.

Studenmund, A. H. (1997). Using Econometrics. A Practical Guide (Addison-Wesley).

Stuetzer, M., Obschonka, M., Brixy, U., Sternberg, R., \& Cantner, U. (2014). Regional characteristics, opportunity perception and entrepreneurial activities. Small Business Economics, 42, 221-244.

Suchman, M. C. (1995). Managing legitimacy: Strategic and institutional approaches. Academy of Management Journal, 20(3), 571 - 610.

Tabellini, G. (2010). Culture and institutions: economic development in the regions of Europe. Journal of the European Economic Association, 8(4), 677-716.

Ter Hofstede, F, Wedel, M., \& Steenkamp, J. B. E. M. (2002). Identifying spatial segments in international markets. Marketing Science, 21(2), 160-177.

Ucabsaran, D., Westhead, P., \& Wright, M. (2008). Opportunity Identification and Pursuit: Does an EntrepreneurÕs Human Capital Matter? Small Business Economics, 30, 153-173

Unger, J.M. Rauch, A., Frese, M., \& Rosenbusch, N. (2011). Human capital and entrepreneurial success: A meta-analytical review. Journal of Business Venturing, 26, 341-358.

Vaillant, Y., \& Lafuente, E. (2007). Do different institutional frameworks condition the influence of local fear of failure and entrepreneurial examples over entrepreneurial activity? Entrepreneurhip \& Regional Development, 19, 313-337.

Westhead, P., Ucbasaran, D., \& Wright, M. (2009). Information search and opportunity identification the importance of prior business ownership experience. International Small Business Journal, 27(6), 659-680.

Westlund, H., Larsson, J.P., \& Olsson, A.R. (2014). Star-ups and local entrepreneurial social capital in the municipalities of Sweden. Regional Studies, 48(6), 974-994.

Wiklund, J., \& Shepherd, D. (2003). Aspiring for, and Achieving Growth: The Moderating Role of Resources and Opportunities. Journal of Management Studies, 40, 1919-1941.

Wright, M., \& Stigliani, I. (2013). Entrepreneurship and growth. International Small Business Journal, 31(1), 3-22. 
Wyrwich, M., Stuetzer, M., \& Sternberg, R. (2016). Entrepreneurial role models, fear of failure, and institutional approval of entrepreneurship: a tale of two regions. Small Business Economics, 46, 467-492. 
Table 1 Individual-level variables - GEM 2008-2014 for Spain

\begin{tabular}{|c|c|c|c|}
\hline Variable & Definition & Mean & S.D. \\
\hline \multicolumn{4}{|l|}{ Dependent variable } \\
\hline $\begin{array}{l}\text { Entrepreneurial growth aspirations } \\
\text { (Ln) }\end{array}$ & $\begin{array}{l}\text { Difference between (the natural logarithms of) the entrepreneurs expected number of } \\
\text { employees in the next five years and the actual number of employees, exclusive of } \\
\text { owners, at the firm's inception }\end{array}$ & 0.70 & 0.47 \\
\hline \multicolumn{4}{|l|}{ Level 1 controls } \\
\hline Age & Current age of participants in years & 39.67 & 10.41 \\
\hline Gender & Dummy: $1=$ male, $0=$ otherwise & 0.60 & 0.48 \\
\hline Necessity entrepreneurial activity & $\begin{array}{l}\text { Dummy: } 1=\text { participants started up by necessity, } 0=\text { participants started up pursuing } \\
\text { an opportunity }\end{array}$ & 0.23 & 0.42 \\
\hline Current employment level & Current number of employees (not counting the owners) & 2.41 & 6.75 \\
\hline Entrepreneurship training & $\begin{array}{l}\text { Dummy: } 1=\text { participants were asked whether they considered had received some } \\
\text { education related to start up an enterprise, } 0=\text { otherwise }\end{array}$ & 0.44 & 0.49 \\
\hline Household income & $\begin{array}{l}\text { Categorical variable: } 1=\text { less than } 10000 \text { euros; } 2=10001-20000 \text { euros; } 3=20001- \\
30000 \text { euros; } 4=30001-40000 \text { euros; } 5=40001-60000 \text { euros; } 6=60000-100000 \\
\text { euros; } 7=100001 \text { euros or more }\end{array}$ & 3.20 & 1.46 \\
\hline Perceived entrepreneurial skills & $\begin{array}{l}\text { Dummy: } 1=\text { Participants believed whether they have the knowledge, skills and } \\
\text { experience required to start-up, } 0=\text { otherwise }\end{array}$ & 0.89 & 0.31 \\
\hline Perceived founding opportunities & $\begin{array}{l}\text { Dummy: } 1=\text { participants were asked whether in the next six month there will be } \\
\text { good opportunities for starting a business in the area where they live, } 0=\text { otherwise }\end{array}$ & 0.34 & 0.47 \\
\hline \multicolumn{4}{|l|}{ Level 1 predictors } \\
\hline Educational attainment & $\begin{array}{l}\text { The categories of educational attainment and the respective years of schooling are: } 1 \\
\text { and } 2=\text { no school leaving certificate }(5 \text { years }) ; 3=\text { primary or secondary school } \\
\text { without vocational training nor general qualifications }(10 \text { years }) ; 4=\text { secondary school } \\
\text { without vocational training }(12 \text { years }) ; 5=\text { technical degree }(14 \text { years }) ; 6 \text { and } 7 \text { Post- } \\
\text { secondary degree ( } 18 \text { years); } 8=\text { postgraduate degree ( } 20 \text { years) }\end{array}$ & 14.88 & 4.53 \\
\hline Entrepreneurial experience & Dummy: $1=$ current owner/manager of an existing business, $0=$ otherwise & 0.07 & 0.26 \\
\hline
\end{tabular}


Table 2 Regional-level variables - various sources, Spanish provinces (NUTS-3)

\begin{tabular}{|c|c|c|c|}
\hline Variable & Definition & Mean & S.D. \\
\hline \multicolumn{4}{|l|}{ Level 2 controls } \\
\hline Population density & $\begin{array}{l}\text { Number of inhabitants per km2. The coefficient has been divided by } 1,000 \text { for } \\
\text { presentation purposes. Source: Spanish Statistics Institute (INE). }\end{array}$ & 0.27 & 0.27 \\
\hline Annual Population rate change (t-1) & $\begin{array}{l}\text { Percentage of change in the annual population rate (lagged one year). Source: Spanish } \\
\text { Statistics Institute (INE). }\end{array}$ & 0.63 & 1.19 \\
\hline Unemployment rate $(\mathrm{t}-1)$ & Unemployment rate (lagged one year). Source: Spanish Statistics Institute (INE). & 16.88 & 8.30 \\
\hline $\begin{array}{l}\text { Annual unemployment rate change } \\
(\mathrm{t}-1)\end{array}$ & $\begin{array}{l}\text { Percentage of change in annual unemployment rate (lagged one year). The coefficient } \\
\text { has been divided by } 100 \text { for presentation purposes. Source: Spanish Statistics Institute } \\
\text { (INE). }\end{array}$ & 0.22 & 0.38 \\
\hline $\mathrm{GDP} / \mathrm{h}$ & $\begin{array}{l}\text { GDP per capita in euros. The coefficient has been divided by 1,000 for presentation } \\
\text { purposes. Source: Spanish Statistics Institute (INE). }\end{array}$ & 23.08 & 4.93 \\
\hline Engagement with education & $\begin{array}{l}\text { Percentage of people aged } 25-64 \text { years with a tertiary education (post-secondary) } \\
\text { degree over the total population. Source: Spanish Statistics Institute (INE). }\end{array}$ & 29.97 & 9.91 \\
\hline Right voters & $\begin{array}{l}\text { Percentage of individuals' who voted in the last elections (2011) a right wing political } \\
\text { party. Source: Spanish Statistics Institute (INE). }\end{array}$ & 53.07 & 7.21 \\
\hline Stock of existing firms & $\begin{array}{l}\text { Proportion of firms in the province over the total active population. Source: Spanish } \\
\text { Statistics Institute (INE). }\end{array}$ & 15.19 & 1.36 \\
\hline Entry rates & Proportion of number of births over the total active population. Source: EUROSTAT. & 1.22 & 0.21 \\
\hline $\begin{array}{l}\text { Social acceptance of } \\
\text { entrepreneurship }\end{array}$ & $\begin{array}{l}\text { Proportion of individuals in the province who consider that most people in their area } \\
\text { would consider starting a new business a desirable career choice. Source: GEM. }\end{array}$ & 0.62 & 0.07 \\
\hline $\begin{array}{l}\text { Regional entrepreneurial role } \\
\text { models }\end{array}$ & $\begin{array}{l}\text { Proportion of individuals in the province who personally know an entrepreneur who } \\
\text { started up in the last two years. Source: GEM. }\end{array}$ & 0.33 & 0.05 \\
\hline
\end{tabular}

Notes: Spatial controls are not explicitly detailed in this table. 
Table 3 Correlation matrix

\begin{tabular}{|c|c|c|c|c|c|c|c|c|c|c|c|c|c|c|c|c|c|c|c|c|c|c|}
\hline Variable & (1) & (2) & (3) & (4) & (5) & (6) & (7) & $(8)$ & (9) & (10) & (11) & (12) & (13) & (14) & (15) & (16) & $(17)$ & (18) & (19) & $(20)$ & (21) & (22) \\
\hline (1) Entrepreneurial growth aspirations (Ln) & 1.00 & & & & & & & & & & & & & & & & & & & & & \\
\hline (2) Age & -0.07 & 1.00 & & & & & & & & & & & & & & & & & & & & \\
\hline (3) Gender & 0.03 & 0.01 & 1.00 & & & & & & & & & & & & & & & & & & & \\
\hline (4) Necessity entrepreneurial activity & -0.03 & 0.03 & -0.06 & 1.00 & & & & & & & & & & & & & & & & & & \\
\hline (5) Current employment level & -0.17 & 0.04 & 0.05 & -0.12 & 1.00 & & & & & & & & & & & & & & & & & \\
\hline (6) Entrepreneurship training & -0.02 & -0.06 & 0.00 & -0.01 & -0.00 & 1.00 & & & & & & & & & & & & & & & & \\
\hline (7) Household income & 0.02 & 0.05 & 0.10 & -0.20 & 0.22 & -0.01 & 1.00 & & & & & & & & & & & & & & & \\
\hline (8) Perceived entrepreneurial skills & 0.02 & 0.02 & 0.03 & -0.05 & 0.02 & 0.08 & 0.06 & 1.00 & & & & & & & & & & & & & & \\
\hline (9) Perceived founding opportunities & 0.09 & -0.02 & 0.03 & -0.09 & 0.05 & 0.02 & 0.10 & 0.05 & 1.00 & & & & & & & & & & & & & \\
\hline (10) Population density & -0.00 & 0.00 & 0.04 & -0.01 & 0.00 & 0.05 & 0.06 & 0.01 & 0.04 & 1.00 & & & & & & & & & & & & \\
\hline (11) Annual population rate change (t-1) & 0.16 & -0.00 & 0.00 & -0.13 & 0.11 & -0.10 & 0.14 & 0.00 & 0.06 & 0.05 & 1.00 & & & & & & & & & & & \\
\hline (12) Unemployment rate $(\mathrm{t}-1)$ & -0.11 & -0.02 & 0.01 & 0.13 & -0.11 & 0.06 & -0.19 & -0.00 & -0.04 & 0.14 & 0.03 & 1.00 & & & & & & & & & & \\
\hline (13) Annual unemployment rate change (t-1) & 0.06 & -0.01 & 0.01 & -0.06 & 0.08 & -0.00 & 0.02 & -0.00 & -0.00 & 0.07 & 0.01 & 0.41 & 1.00 & & & & & & & & & \\
\hline (14) GDP/h & 0.01 & 0.03 & 0.00 & -0.07 & 0.02 & 0.00 & 0.18 & 0.00 & 0.06 & -0.16 & 0.43 & 0.25 & -0.52 & 1.00 & & & & & & & & \\
\hline (15) Engagement with education & -0.09 & 0.00 & -0.01 & 0.08 & -0.09 & 0.06 & -0.07 & -0.00 & -0.02 & -0.36 & -0.04 & -0.46 & 0.32 & -0.34 & 1.00 & & & & & & & \\
\hline (16) Right voters & 0.01 & -0.03 & 0.02 & 0.01 & 0.00 & -0.00 & -0.03 & -0.00 & 0.00 & 0.37 & 0.05 & 0.14 & 0.07 & -0.16 & -0.36 & 1.00 & & & & & & \\
\hline (17) Stock of existing firms & 0.06 & 0.03 & -0.00 & -0.08 & 0.03 & -0.02 & 0.15 & 0.01 & 0.04 & -0.04 & 0.26 & 0.24 & -0.53 & 0.12 & 0.43 & -0.17 & 1.00 & & & & & \\
\hline (18) Entry rates & 0.01 & 0.01 & -0.00 & 0.05 & -0.03 & -0.01 & -0.01 & 0.00 & 0.03 & 0.18 & 0.25 & -0.14 & $\mathbf{0 . 3 2}$ & -0.09 & -0.10 & -0.01 & 0.28 & 1.00 & & & & \\
\hline (19) Social acceptance of entrepreneurship & 0.10 & 0.00 & 0.00 & -0.09 & 0.06 & -0.05 & 0.13 & 0.01 & 0.03 & -0.08 & 0.02 & 0.54 & -0.47 & 0.23 & 0.20 & -0.19 & 0.30 & -0.14 & 1.00 & & & \\
\hline (20) Regional entrepreneurial role models & 0.19 & 0.01 & -0.02 & -0.04 & 0.04 & -0.14 & 0.07 & -0.01 & 0.08 & 0.00 & -0.21 & 0.27 & -0.09 & 0.01 & -0.16 & -0.22 & 0.08 & 0.13 & 0.18 & 1.00 & & \\
\hline (21) Educational attainment & -0.12 & -0.09 & -0.00 & 0.05 & -0.05 & 0.19 & -0.02 & 0.04 & -0.03 & -0.02 & 0.08 & -0.51 & 0.46 & -0.25 & -0.06 & 0.34 & -0.20 & 0.20 & -0.29 & -0.42 & 1.00 & \\
\hline (22) Entrepreneurial experience & -0.05 & 0.11 & 0.02 & -0.06 & 0.15 & -0.04 & 0.13 & 0.04 & 0.03 & -0.01 & -0.03 & 0.13 & -0.14 & 0.04 & 0.03 & -0.07 & 0.09 & -0.02 & 0.18 & 0.11 & -0.16 & 1.00 \\
\hline
\end{tabular}

Notes: Correlation coefficients displayed in bold are significant at the $0.1 \%$. Spatial controls are not included in this table due to space restrictions. 
Table 4 Multilevel random intercept model predicting entrepreneurial growth aspirations

\begin{tabular}{|c|c|c|c|c|c|c|c|c|}
\hline & Model 1 & Model 2 & Model 3 & Model 4 & Model 5 & Model 6 & Model 7 & Model 8 \\
\hline \multicolumn{9}{|l|}{ Individual-level controls } \\
\hline Age & $\begin{array}{l}-0.0028^{* *} \\
(0.0011)\end{array}$ & $\begin{array}{l}-0.0014 \\
(0.0013)\end{array}$ & $\begin{array}{l}-0.0013 \\
(0.0013)\end{array}$ & $\begin{array}{l}-0.0015 \\
(0.0013)\end{array}$ & $\begin{array}{l}-0.0015 \\
(0.0013)\end{array}$ & $\begin{array}{l}-0.0012 \\
(0.0013)\end{array}$ & $\begin{array}{l}-0.0016 \\
(0.0013)\end{array}$ & $\begin{array}{l}-0.0013 \\
(0.0013)\end{array}$ \\
\hline Age squared & $\begin{array}{l}-0.0002^{* *} \\
(0.0000)\end{array}$ & $\begin{array}{l}-0.0002^{* *} \\
(0.0001)\end{array}$ & $\begin{array}{l}-0.0002^{* *} \\
(0.0001)\end{array}$ & $\begin{array}{l}-0.00030^{* *} \\
(0.0001)\end{array}$ & $\begin{array}{l}-0.0002 * * \\
(0.0001)\end{array}$ & $\begin{array}{l}-0.0002^{* *} \\
(0.0001)\end{array}$ & $\begin{array}{l}-0.0003^{* *} \\
(0.0001)\end{array}$ & $\begin{array}{l}-0.0002^{* *} \\
(0.000)\end{array}$ \\
\hline Gender & $\begin{array}{l}0.0576^{* *} \\
(0.0233)\end{array}$ & $\begin{array}{l}0.0595^{* *} \\
(0.0262)\end{array}$ & $\begin{array}{l}0.0593 * * \\
(0.0261)\end{array}$ & $\begin{array}{l}0.0570^{* *} \\
(0.0261)\end{array}$ & $\begin{array}{l}0.0566 * * \\
(0.0261)\end{array}$ & $\begin{array}{l}0.0593 * * \\
(0.0261)\end{array}$ & $\begin{array}{l}0.0536^{* * *} \\
(0.0261)\end{array}$ & $\begin{array}{l}0.0530 * * \\
(0.0260)\end{array}$ \\
\hline Necessity entrepreneurial activity & $\begin{array}{l}-0.0297 \\
(0.0271)\end{array}$ & $\begin{array}{l}-0.0194 \\
(0.0300)\end{array}$ & $\begin{array}{l}-0.0195 \\
(0.0300)\end{array}$ & $\begin{array}{l}-0.0213 \\
(0.0300)\end{array}$ & $\begin{array}{l}-0.0215 \\
(0.0300)\end{array}$ & $\begin{array}{l}-0.0219 \\
(0.0301)\end{array}$ & $\begin{array}{l}-0.0214 \\
(0.0299)\end{array}$ & $\begin{array}{l}-0.0246 \\
(0.0299)\end{array}$ \\
\hline Current employment level & $\begin{array}{l}-0.0747^{* *} \\
(0.0141)\end{array}$ & $\begin{array}{l}-0.0469^{* *} \\
(0.0157)\end{array}$ & $\begin{array}{l}-0.0467 * * \\
(0.0157)\end{array}$ & $\begin{array}{l}-0.0481^{* *} \\
(0.0157)\end{array}$ & $\begin{array}{l}-0.0478^{* *} \\
(0.0157)\end{array}$ & $\begin{array}{l}-0.0470^{* *} \\
(0.0157)\end{array}$ & $\begin{array}{l}-0.0473^{* *} \\
(0.0157)\end{array}$ & $\begin{array}{l}-0.0475^{* *} \\
(0.0156)\end{array}$ \\
\hline Entrepreneurship training & $\begin{array}{c}0.0143 \\
(0.0228)\end{array}$ & $\begin{array}{c}0.0096 \\
(0.0261)\end{array}$ & $\begin{array}{c}0.0099 \\
(0.0261)\end{array}$ & $\begin{array}{c}0.0164 \\
(0.0261)\end{array}$ & $\begin{array}{c}0.0171 \\
(0.0261)\end{array}$ & $\begin{array}{c}0.0100 \\
(0.0260)\end{array}$ & $\begin{array}{c}0.0120 \\
(0.0260)\end{array}$ & $\begin{array}{c}0.0126 \\
(0.0259)\end{array}$ \\
\hline Household income & $\begin{array}{l}-0.0127 \\
(0.0081)\end{array}$ & $\begin{array}{l}-0.0119 \\
(0.0094)\end{array}$ & $\begin{array}{l}-0.0122 \\
(0.0094)\end{array}$ & $\begin{array}{l}-0.0115 \\
(0.0094)\end{array}$ & $\begin{array}{l}-0.0119 \\
(0.0094)\end{array}$ & $\begin{array}{l}-0.0117 \\
(0.0094)\end{array}$ & $\begin{array}{l}-0.0106 \\
(0.0094)\end{array}$ & $\begin{array}{l}-0.0102 \\
(0.0093)\end{array}$ \\
\hline Perceived entrepreneurial skills & $\begin{array}{l}0.0768^{* *} \\
(0.0363)\end{array}$ & $\begin{array}{l}0.0804^{* *} \\
(0.0399)\end{array}$ & $\begin{array}{l}0.0817^{* *} \\
(0.0400)\end{array}$ & $\begin{array}{l}0.0803^{* *} \\
(0.0398)\end{array}$ & $\begin{array}{l}0.0824 * * \\
(0.0399)\end{array}$ & $\begin{array}{c}0.0771^{*} \\
(0.0399)\end{array}$ & $\begin{array}{l}0.0810^{* *} \\
(0.0397)\end{array}$ & $\begin{array}{c}0.0770^{*} \\
(0.0397)\end{array}$ \\
\hline Perceived founding opportunities & $\begin{array}{r}0.0506^{*} \\
(0.0261)\end{array}$ & $\begin{array}{r}0.0586^{*} \\
(0.0300)\end{array}$ & $\begin{array}{l}0.0596^{* *} \\
(0.0300)\end{array}$ & $\begin{array}{l}0.0596^{* *} \\
(0.0299)\end{array}$ & $\begin{array}{l}0.0613^{* *} \\
(0.0299)\end{array}$ & $\begin{array}{l}0.0613^{* *} \\
(0.0300)\end{array}$ & $\begin{array}{l}0.0606^{* *} \\
(0.0299)\end{array}$ & $\begin{array}{l}0.0642 * * \\
(0.0299)\end{array}$ \\
\hline Regional-level controls & & & & & & & & \\
\hline Population density & $\begin{array}{c}0.1193 \\
(0.0947)\end{array}$ & $\begin{array}{c}0.1445 \\
(0.1062)\end{array}$ & $\begin{array}{c}0.1495 \\
(0.1064)\end{array}$ & $\begin{array}{c}0.1477 \\
(0.1060)\end{array}$ & $\begin{array}{c}0.1556 \\
(0.1062)\end{array}$ & $\begin{array}{c}0.1658 \\
(0.1069)\end{array}$ & $\begin{array}{c}0.1466 \\
(0.1057)\end{array}$ & $\begin{array}{c}0.1734 \\
(0.1064)\end{array}$ \\
\hline Annual population rate change (t-1) & $\begin{array}{c}0.0018 \\
(0.0220)\end{array}$ & $\begin{array}{c}0.0003 \\
(0.0240)\end{array}$ & $\begin{array}{c}0.0000 \\
(0.0240)\end{array}$ & $\begin{array}{c}0.0009 \\
(0.0239)\end{array}$ & $\begin{array}{c}0.0005 \\
(0.0239)\end{array}$ & $\begin{array}{c}0.0009 \\
(0.0239)\end{array}$ & $\begin{array}{c}0.0012 \\
(0.0238)\end{array}$ & $\begin{array}{c}0.0020 \\
(0.0238)\end{array}$ \\
\hline Unemployment rate $(\mathrm{t}-1)$ & $\begin{array}{l}-0.0027 \\
(0.0052)\end{array}$ & $\begin{array}{l}-0.0044 \\
(0.0058)\end{array}$ & $\begin{array}{l}-0.0044 \\
(0.0058)\end{array}$ & $\begin{array}{l}-0.0045 \\
(0.0058)\end{array}$ & $\begin{array}{l}-0.0046 \\
(0.0058)\end{array}$ & $\begin{array}{l}-0.0058 \\
(0.0059)\end{array}$ & $\begin{array}{l}-0.0036 \\
(0.0058)\end{array}$ & $\begin{array}{l}-0.0054 \\
(0.0058)\end{array}$ \\
\hline Annual unemployment rate change (t-1) & $\begin{array}{l}-0.0891 \\
(0.0557)\end{array}$ & $\begin{array}{l}-0.0853 \\
(0.0605)\end{array}$ & $\begin{array}{l}-0.0855 \\
(0.0605)\end{array}$ & $\begin{array}{l}-0.0919 \\
(0.0604)\end{array}$ & $\begin{array}{l}-0.0926 \\
(0.0604)\end{array}$ & $\begin{array}{l}-0.0921 \\
(0.0606)\end{array}$ & $\begin{array}{l}-0.0791 \\
(0.0603)\end{array}$ & $\begin{array}{l}-0.0873 \\
(0.0603)\end{array}$ \\
\hline GDP/h & $\begin{array}{l}-0.0074 \\
(0.0058)\end{array}$ & $\begin{array}{l}-0.0115^{*} \\
(0.0066)\end{array}$ & $\begin{array}{l}-0.0117^{*} \\
(0.0066)\end{array}$ & $\begin{array}{l}-0.0115^{*} \\
(0.0066)\end{array}$ & $\begin{array}{l}-0.0117^{*} \\
(0.0066)\end{array}$ & $\begin{array}{l}-0.0126^{*} \\
(0.0067)\end{array}$ & $\begin{array}{r}-0.0117^{*} \\
(0.0066)\end{array}$ & $\begin{array}{l}-0.0130^{*} \\
(0.0066)\end{array}$ \\
\hline Engagement with education & $\begin{array}{l}-0.0014 \\
(0.0019)\end{array}$ & $\begin{array}{l}-0.0014 \\
(0.0022)\end{array}$ & $\begin{array}{l}-0.0015 \\
(0.0022)\end{array}$ & $\begin{array}{l}-0.0013 \\
(0.0022)\end{array}$ & $\begin{array}{l}-0.0014 \\
(0.0022)\end{array}$ & $\begin{array}{l}-0.0019 \\
(0.0023)\end{array}$ & $\begin{array}{c}-0.0013 \\
(0.0022)\end{array}$ & $\begin{array}{l}-0.0019 \\
(0.0022)\end{array}$ \\
\hline Right voters & $\begin{array}{c}0.0030 \\
(0.0027)\end{array}$ & $\begin{array}{c}0.0048 \\
(0.0030)\end{array}$ & $\begin{array}{c}0.0047 \\
(0.0030)\end{array}$ & $\begin{array}{c}0.0048 \\
(0.0030)\end{array}$ & $\begin{array}{c}0.0047 \\
(0.0030)\end{array}$ & $\begin{array}{c}0.0047 \\
(0.0030)\end{array}$ & $\begin{array}{l}0.0055^{*} \\
(0.0030)\end{array}$ & $\begin{array}{l}0.0055^{*} \\
(0.0030)\end{array}$ \\
\hline Stock of existing firms & $\begin{array}{l}-0.0146 \\
(0.0155)\end{array}$ & $\begin{array}{l}-0.0172 \\
(0.0170)\end{array}$ & $\begin{array}{l}-0.0179 \\
(0.0170)\end{array}$ & $\begin{array}{l}-0.0175 \\
(0.0169)\end{array}$ & $\begin{array}{l}-0.0187 \\
(0.0170)\end{array}$ & $\begin{array}{l}-0.0175 \\
(0.0170)\end{array}$ & $\begin{array}{l}-0.0184 \\
(0.0169)\end{array}$ & $\begin{array}{l}-0.0189 \\
(0.0169)\end{array}$ \\
\hline Entry rates & $\begin{array}{l}-0.0046 \\
(0.1007)\end{array}$ & $\begin{array}{l}0.0256 \\
(0.1091)\end{array}$ & $\begin{array}{c}0.0332 \\
(0.1097)\end{array}$ & $\begin{array}{l}0.0261 \\
(0.1089)\end{array}$ & $\begin{array}{c}0.0379 \\
(0.1094)\end{array}$ & $\begin{array}{c}0.0250 \\
(0.1090)\end{array}$ & $\begin{array}{c}0.0276 \\
(0.1086)\end{array}$ & $\begin{array}{c}0.0270 \\
(0.1085)\end{array}$ \\
\hline Social acceptance of entrepreneurship & $\begin{array}{c}0.0582 \\
(0.2690)\end{array}$ & $\begin{array}{c}0.2239 \\
(0.3035)\end{array}$ & $\begin{array}{c}0.1953 \\
(0.3063)\end{array}$ & $\begin{array}{c}0.1443 \\
(0.3042)\end{array}$ & $\begin{array}{c}0.0963 \\
(0.3075)\end{array}$ & $\begin{array}{c}0.1912 \\
(0.3039)\end{array}$ & $\begin{array}{c}0.2727 \\
(0.3024)\end{array}$ & $\begin{array}{c}0.2346 \\
(0.3026)\end{array}$ \\
\hline Regional entrepreneurial role models & $\begin{array}{l}-0.0727 \\
(0.3949)\end{array}$ & $\begin{array}{l}0.2307 \\
(0.4497)\end{array}$ & $\begin{array}{l}0.1997 \\
(0.4519)\end{array}$ & $\begin{array}{l}0.2196 \\
(0.4486)\end{array}$ & $\begin{array}{l}0.1712 \\
(0.4509)\end{array}$ & $\begin{array}{l}0.1639 \\
(0.4511)\end{array}$ & $\begin{array}{l}-0.0007 \\
(0.4519)\end{array}$ & $\begin{array}{l}-0.0978 \\
(0.4537)\end{array}$ \\
\hline Individual-level predictors & & & & & & & & \\
\hline Educational attainment (H1) & & $\begin{array}{l}0.0105^{* *} \\
(0.0040)\end{array}$ & $\begin{array}{l}0.0099 * * \\
(0.0041)\end{array}$ & $\begin{array}{l}0.0104 * * \\
(0.0040)\end{array}$ & $\begin{array}{l}0.0095 * * \\
(0.0041)\end{array}$ & $\begin{array}{l}0.0097 * * \\
(0.0040)\end{array}$ & $\begin{array}{l}0.0110^{* *} \\
(0.0040)\end{array}$ & $\begin{array}{l}0.0101 * * \\
(0.0040)\end{array}$ \\
\hline Entrepreneurial experience $(\mathrm{H} 2)$ & & $\begin{array}{l}-0.2180^{* * * *} \\
(0.0544)\end{array}$ & $\begin{array}{l}-0.2160 * * * \\
(0.0545)\end{array}$ & $\begin{array}{l}-0.3813^{* * * *} \\
(0.0809)\end{array}$ & $\begin{array}{l}-0.3863 * * * \\
(0.0811)\end{array}$ & $\begin{array}{l}-0.2116^{* * *} \\
(0.0545)\end{array}$ & $\begin{array}{l}-0.7487 * * * \\
(0.1513)\end{array}$ & $\begin{array}{l}-0.7716^{* * *} \\
(0.1515)\end{array}$ \\
\hline $\begin{array}{l}\text { Cross-level interaction } \\
\text { Educational attainment } * \text { Social } \\
\text { acceptance of entrepreneurship (H3a) }\end{array}$ & & & $\begin{array}{l}0.0367 \\
(0.0540)\end{array}$ & & $\begin{array}{c}0.0566 \\
(0.0544)\end{array}$ & & & \\
\hline $\begin{array}{l}\text { Entrepreneurial experience } * \text { Social } \\
\text { acceptance of entrepreneurship }(\mathrm{H} 3 \mathrm{~b})\end{array}$ & & & & $\begin{array}{l}2.8156^{* *} \\
(1.0353)\end{array}$ & $\begin{array}{l}2.9562 * * \\
(1.0437)\end{array}$ & & & \\
\hline $\begin{array}{l}\text { Educational attainment } * \text { Regional } \\
\text { entrepreneurial role models }(\mathrm{H} 4 \mathrm{a})\end{array}$ & & & & & & $0.1054^{*}$ & & $0.1319 * *$ \\
\hline $\begin{array}{l}\text { Entrepreneurial experience } * \text { Regional } \\
\text { entrepreneurial role models }(\mathrm{H} 4 \mathrm{~b})\end{array}$ & & & & & & $(0.0638)$ & $7.0402 * * *$ & $\begin{array}{l}(0.0638) \\
7.4492 * * *\end{array}$ \\
\hline & & & & & & & $(1.8738)$ & $(1.8817)$ \\
\hline Intercept & $\begin{array}{c}0.9041 * \\
(0.5058)\end{array}$ & $\begin{array}{c}0.4085 \\
(0.5837)\end{array}$ & $\begin{array}{c}0.7573 \\
(0.5723)\end{array}$ & $\begin{array}{c}0.5590 \\
(0.5701)\end{array}$ & $\begin{array}{c}0.7989 \\
(0.5710)\end{array}$ & $\begin{array}{c}0.7696 \\
(0.5914)\end{array}$ & $\begin{array}{c}0.3895 \\
(0.5898)\end{array}$ & $\begin{array}{c}0.7120 \\
(0.5887)\end{array}$ \\
\hline Industry fixed effects & Yes & Yes & Yes & Yes & Yes & Yes & Yes & Yes \\
\hline Years fixed effects & Yes & Yes & Yes & Yes & Yes & Yes & Yes & Yes \\
\hline$N$ of observations & 1845 & 1581 & 1581 & 1581 & 1581 & 1581 & 1581 & 1581 \\
\hline$N$ of groups (provinces) & 50 & 50 & 50 & 50 & 50 & 50 & 50 & 50 \\
\hline Wald chi-squared & $137.42 * * *$ & $131.49^{* * *}$ & $131.99 * * *$ & $139.50 * * *$ & $140.68 * * *$ & $134.45^{* * *}$ & $146.78 * * *$ & $151.45^{* * *}$ \\
\hline Log-likelihood & -1229.8078 & -1120.8704 & -1120.6397 & -1117.1813 & -1116.6391 & -1119.5065 & -1113.8436 & -1111.7092 \\
\hline Degrees of freedom & 39 & 41 & 42 & 42 & 43 & 42 & 42 & 43 \\
\hline $\mathrm{AIC}^{\mathrm{a}}$ & 2537.6156 & 2323.7408 & 2325.2794 & 2318.3626 & 2319.2782 & 2323.013 & 2311.6872 & 2309.4184 \\
\hline
\end{tabular}

Notes: Reported values are non-standardized $\beta$ coefficients. Robust standard errors are given in parentheses. ${ }^{\text {a }}$ AIC is Akaike's information criterion $=2 k-2 \mathrm{x}\left(\log\right.$ likelihood), where $k$ indicates the degrees of freedom. ${ }^{*} p<0.10,{ }^{* *} p<0.05,{ }^{* *} p<0.001$; two-tailed significance. The spatial controls are included in all the models. 
Figure 1 Multilevel conceptual framework and hypotheses

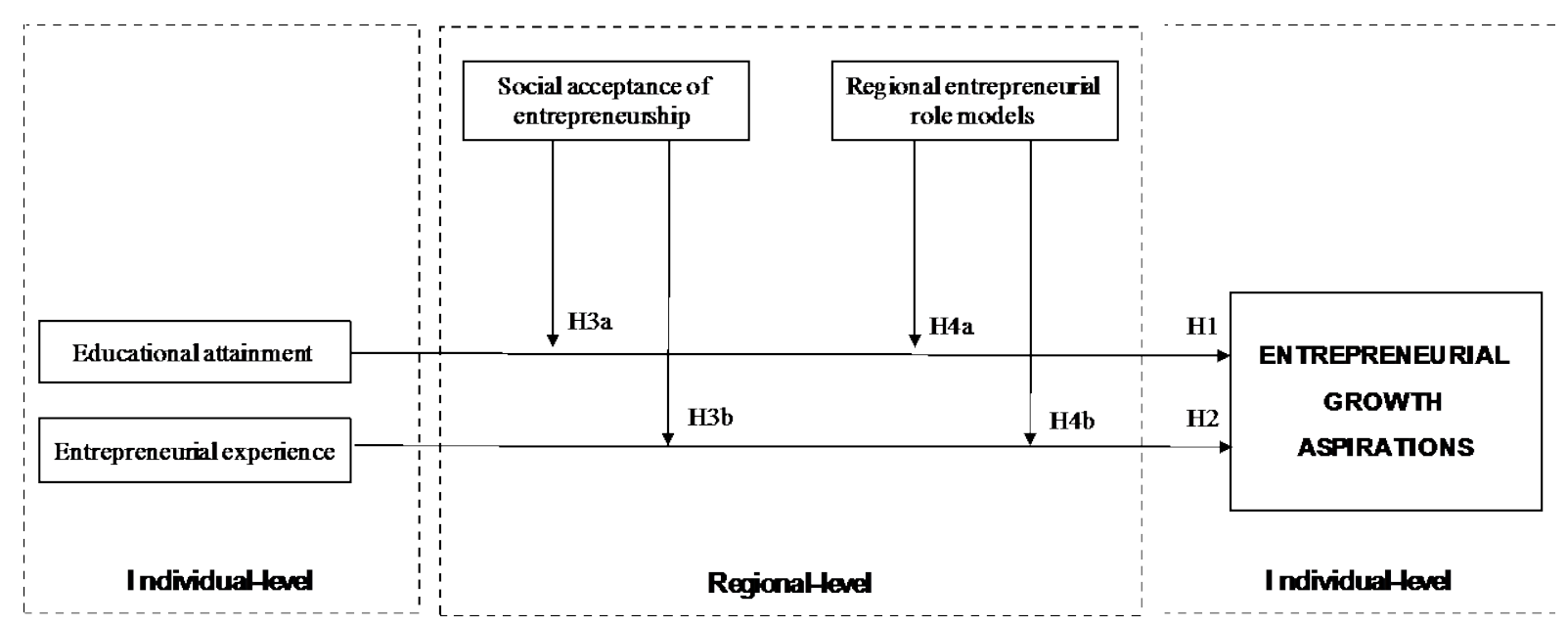


Figure 2 Moderating effect of social acceptance of entrepreneurship on the relationship between entrepreneurship experience and entrepreneurial growth aspirations

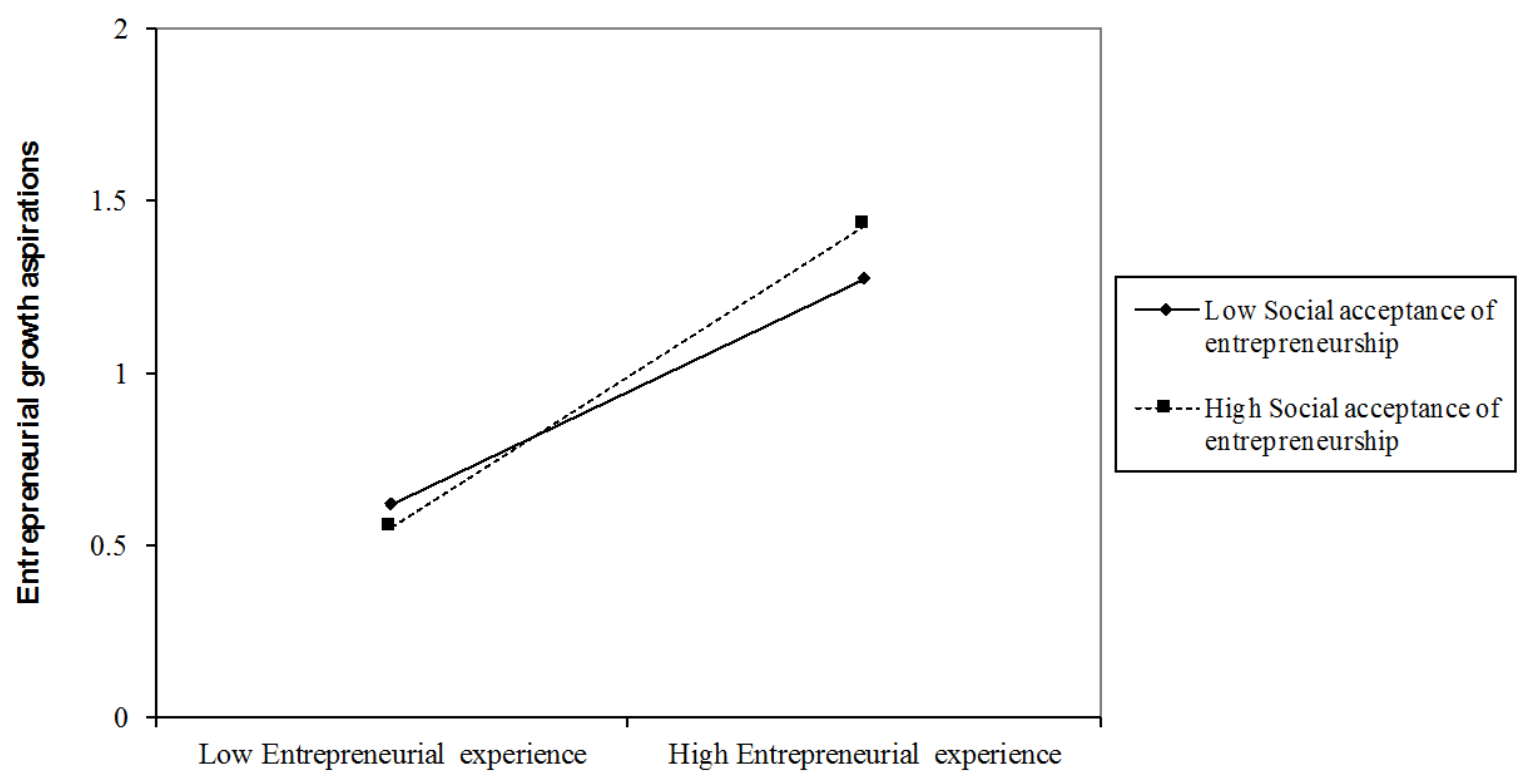


Figure 3 Moderating effect of regional entrepreneurial role models on the relationship between educational attainment and entrepreneurial growth aspirations

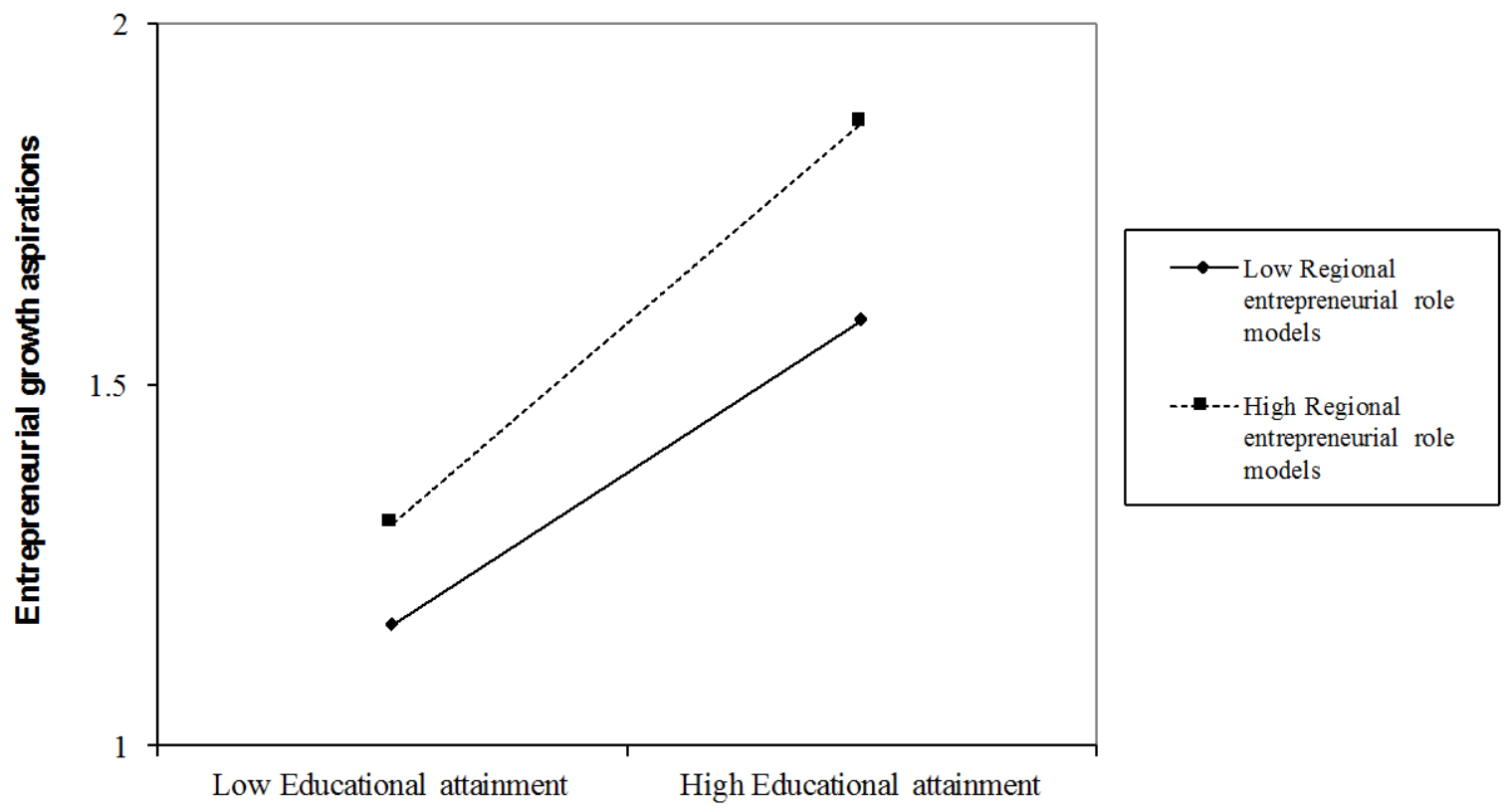


Figure 4 Moderating effect of regional entrepreneurial role models on the relationship between entrepreneurial experience and entrepreneurial growth aspirations

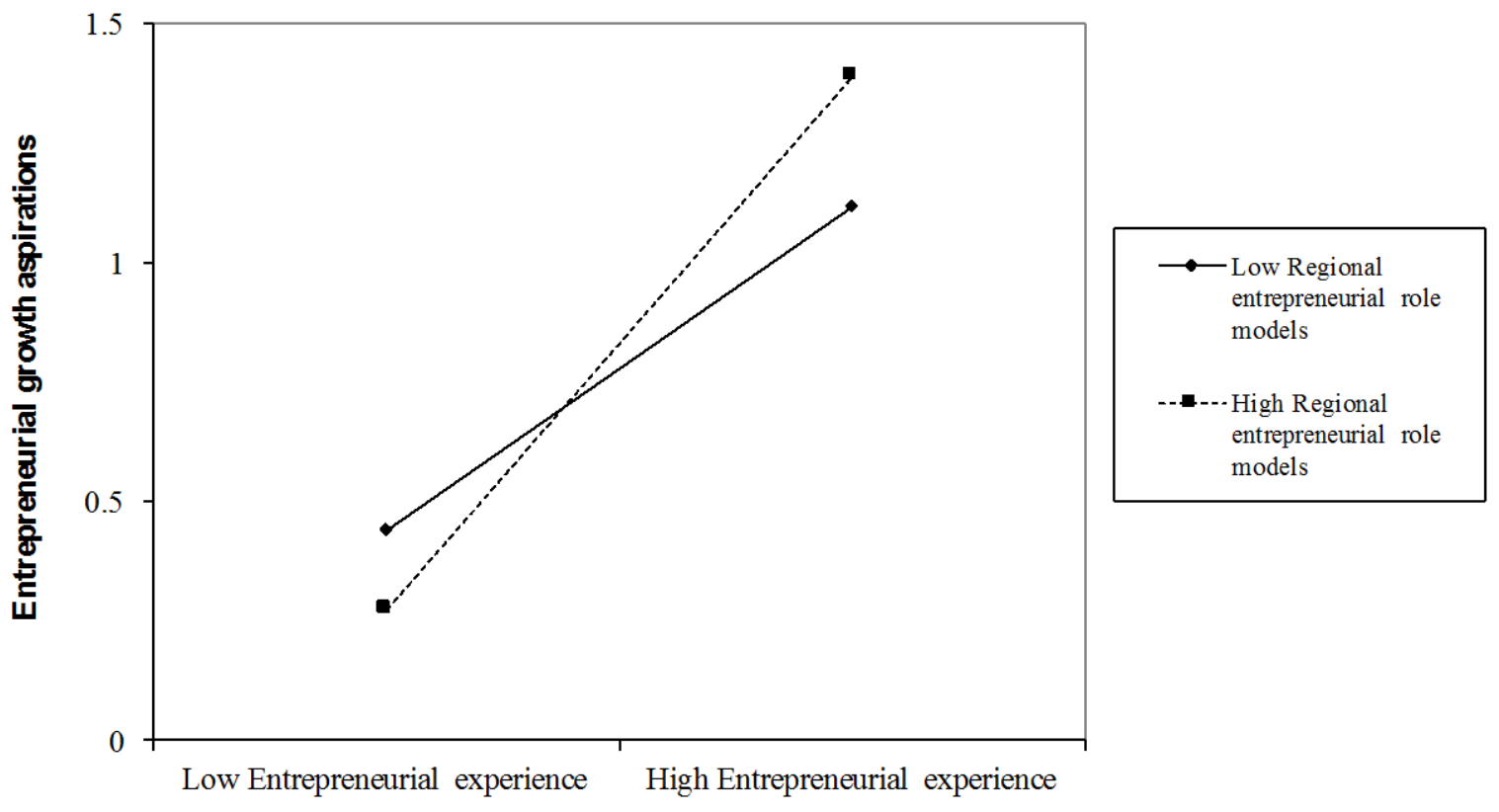

